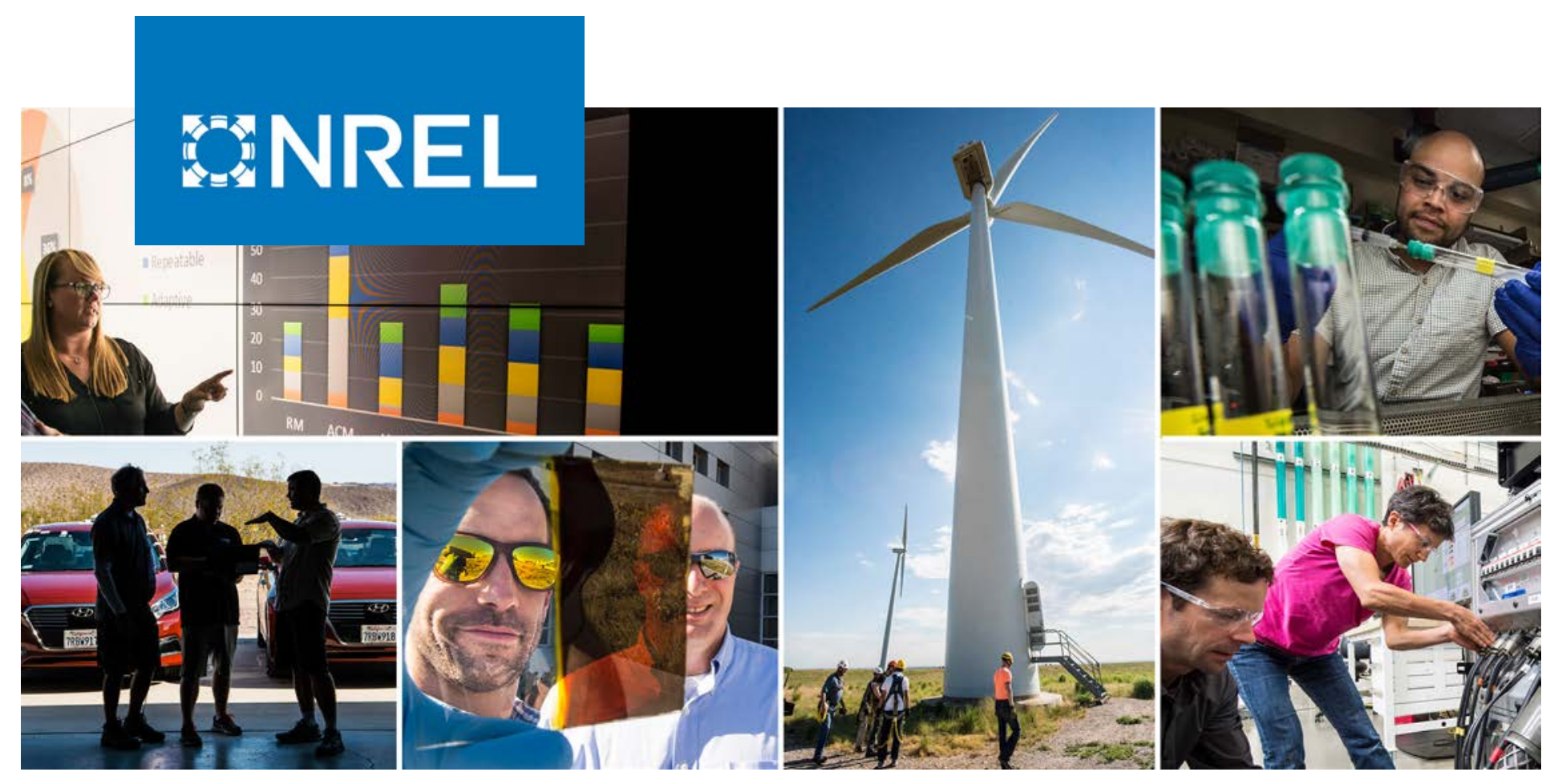

\title{
Manufacturing Cost Analysis for Proton Exchange Membrane Water Electrolyzers
}

\author{
Ahmad Mayyas, Mark Ruth, Bryan Pivovar, Guido Bender, \\ and Keith Wipke
}

National Renewable Energy Laboratory

NREL is a national laboratory of the U.S. Department of Energy

Office of Energy Efficiency \& Renewable Energy

Operated by the Alliance for Sustainable Energy, LLC

This report is available at no cost from the National Renewable Energy Laboratory (NREL) at www.nrel.gov/publications.
Technical Report

NREL/TP-6A20-72740

August 2019 


\title{
ENREL
}

\section{Manufacturing Cost Analysis for Proton Exchange Membrane Water Electrolyzers}

\author{
Ahmad Mayyas, Mark Ruth, Bryan Pivovar, Guido Bender, \\ and Keith Wipke
}

National Renewable Energy Laboratory

Suggested Citation (Arial 12 pt Bold)

Mayyas, Ahmad, Mark Ruth, Bryan Pivovar, Guido Bender, and Keith Wipke. 2018.

Manufacturing Cost Analysis for Proton Exchange Membrane Water Electrolyzers.

Golden, CO: National Renewable Energy Laboratory. NREL/TP-6A20-72740.

https://www.nrel.gov/docs/fy10osti/72740.pdf.

NREL is a national laboratory of the U.S. Department of Energy Office of Energy Efficiency \& Renewable Energy Operated by the Alliance for Sustainable Energy, LLC

This report is available at no cost from the National Renewable Energy Laboratory (NREL) at www.nrel.gov/publications.

Contract No. DE-AC36-08GO28308
Technical Report

NREL/TP-6A20-72740

August 2019

National Renewable Energy Laboratory 15013 Denver West Parkway Golden, CO 80401

303-275-3000 • www.nrel.gov 


\section{NOTICE}

This work was authored by the National Renewable Energy Laboratory, operated by Alliance for Sustainable Energy, LLC, for the U.S. Department of Energy (DOE) under Contract No. DE-AC36-08GO28308. Funding provided by the Laboratory Directed Research and Development (LDRD) Program at NREL. The views expressed herein do not necessarily represent the views of the DOE or the U.S. Government.

This report is available at no cost from the National Renewable Energy Laboratory (NREL) at www.nrel.gov/publications.

U.S. Department of Energy (DOE) reports produced after 1991 and a growing number of pre-1991 documents are available free via www.OSTI.gov.

Cover Photos by Dennis Schroeder: (clockwise, left to right) NREL 51934, NREL 45897, NREL 42160, NREL 45891, NREL 48097, NREL 46526.

NREL prints on paper that contains recycled content. 


\section{Acknowledgment}

This work was supported by the Laboratory Directed Research and Development (LDRD) Program at the National Renewable Energy Laboratory (LDRD 10012-17.02.01 H2 @scale) 


\section{Executive Summary}

Hydrogen is produced by several means, including water electrolysis, in which water molecules are split into hydrogen and oxygen molecules. Low cost high-capacity electrolysis system is a key technology that can support greater deployment of zero-carbon hydrogen for a variety of applications and represents a technology that can potentially facilitate integration of greater renewable electricity sources. While there are several commercial electrolysis systems, proton exchange membrane (PEM) technology has emerged as a development opportunity because of its versatility. High differential operating pressure, variable operating condition potential, high current densities, high power densities, and high efficiencies are among the advantages of the PEM electrolyzer over other commercial or near-commercial electrolysis technologies. In this report, we discuss bottom-up manufacturing cost analysis for the PEM electrolyzers across various power ratings at several annual production rates. We also study the impact of manufacturing economies of scale on the cost of the PEM electrolyzer and how this can be linked to reducing the cost of hydrogen production.

Bottom up costing models were developed for the kay parts in the stack. Cost model results show that direct material costs dominate stack costs at high production volume (Figure ES-1). Stack cost for 1MW system can be reduced from $\$ 237 / \mathrm{kW}( \pm 10 \%)$ at annual production rate of $10 \mathrm{MW} / \mathrm{yr}$ (e.g., 1-MW systems at a production rate of $10 \mathrm{unit} /$ year) to about $\$ 101( \pm 10 \%)$ at annual production rate of 1,000 MW (e.g., 1-MW systems at a production rate of 1,000 unit/year). We expect smaller cost reductions in the "balance of plant" cost because most parts are outsourced from suppliers that are manufacturing the components for multiple markets and thus are at high volume already. Depending on the production volume, we found that CCM shares about 26\%-47\% for $200-\mathrm{kW}$ PEM stack and about $36 \%-47 \%$ for the 1-MW stack, with PTL contributing around $17 \%-25 \%$ of the stack cost, bipolar plates about $12 \%-$ $21 \%$, and end plates and assembly near 3\%-13\%. Parametric sensitivity analysis shows that the final stack cost is sensitive to manufacturing process yields, power density of the cell, gold layer thickness on porous transport layer and bipolar plates and Pt loading in the catalyst coated membrane. Balance-ofplant cost for a 1-MW electrolyzer contribute to about two-thirds of the system cost, with power electronics contributing half the BOP cost, while the water circulation and hydrogen processing subsystems each share about one-fifth of the BOP cost.

We also analyzed several scenarios to study the effect of changing certain cell design parameters and manufacturing process on the stack and system cost for PEM electrolyzers. These proposed scenarios represent cases for the future PEM system design and the potential cost reductions when more advanced manufacturing processes are introduced and adopted in PEM electrolyzer production (Figure ES-2). Some scenarios we ran here include adoption of the high-throughput, automated manufacturing processes that have high process yields, such as roll-to-roll manufacturing of catalyst-coated membrane and advanced coating processes for metal plates which could reduce the cost for the PEM electrolyzer stack from $\$ 237 / \mathrm{kW}( \pm 10 \%)$ at a production volume of $10 \mathrm{MW}$ (e.g., 1-MW systems at a production rate of 10 units/year) to $\$ 69 / \mathrm{kW}( \pm 10 \%)$ at 1,000 MW (e.g., 1-MW systems at 1,000 unit/year). System cost of 1-MW electrolyzer, including stack and balance of plant, could also be reduced through manufacturing economies of scale - from $\$ 561 / \mathrm{kW}( \pm 10 \%)$ at 10 units/year to $\$ 265 / \mathrm{kW}( \pm 10 \%)$ at 1,000 units/year. The base year for the analysis is 2015 , so all cost numbers presented in this report are expressed in 2015 dollars.

In terms of the effect of the electrolysis system capital cost on hydrogen production cost, we found that electricity price in addition to the electrolyzer capital cost play key role in determining the cost of 
hydrogen production via water electrolysis. Thus, any cost reduction in the electrolyzer cost will help reduce the cost of hydrogen production process.

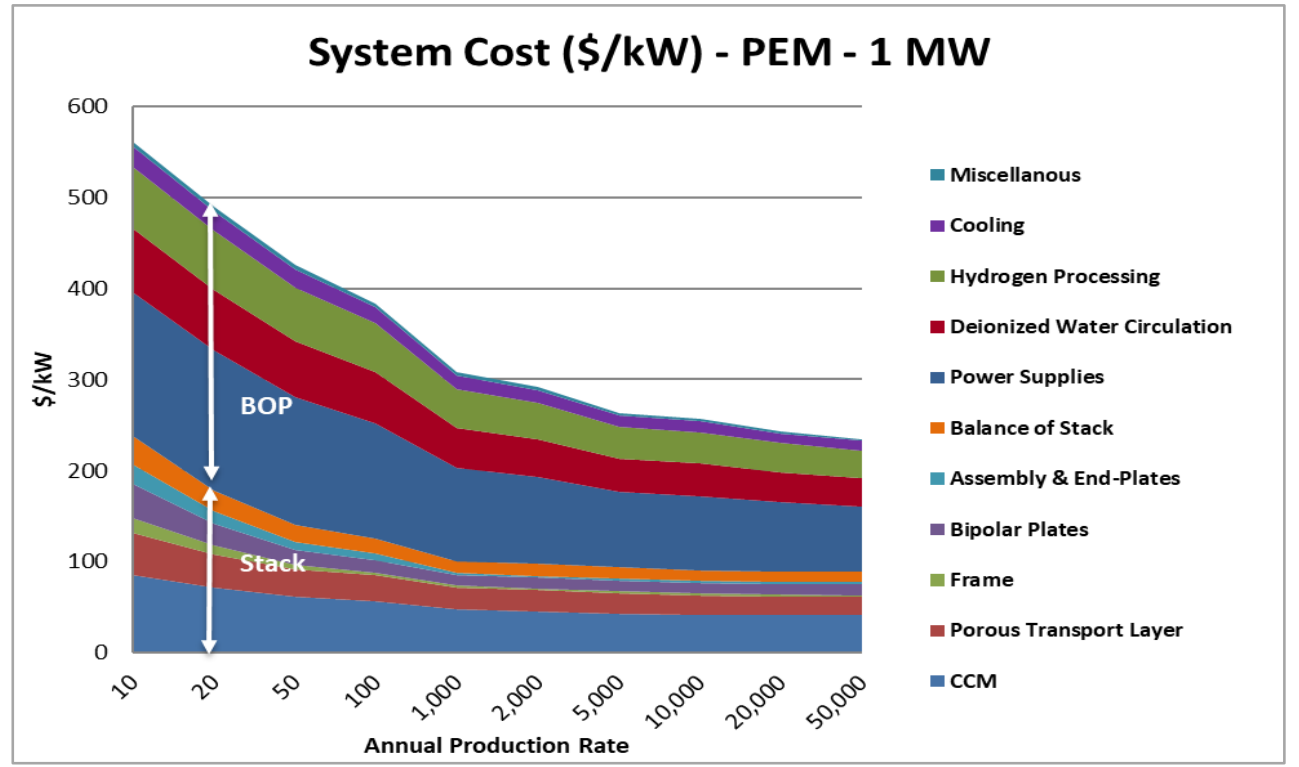

Figure ES-1. 1-MW PEM electrolyzer system cost at different annual production rates

(The annual production rate is the number of electrolyzer systems produced in one year)

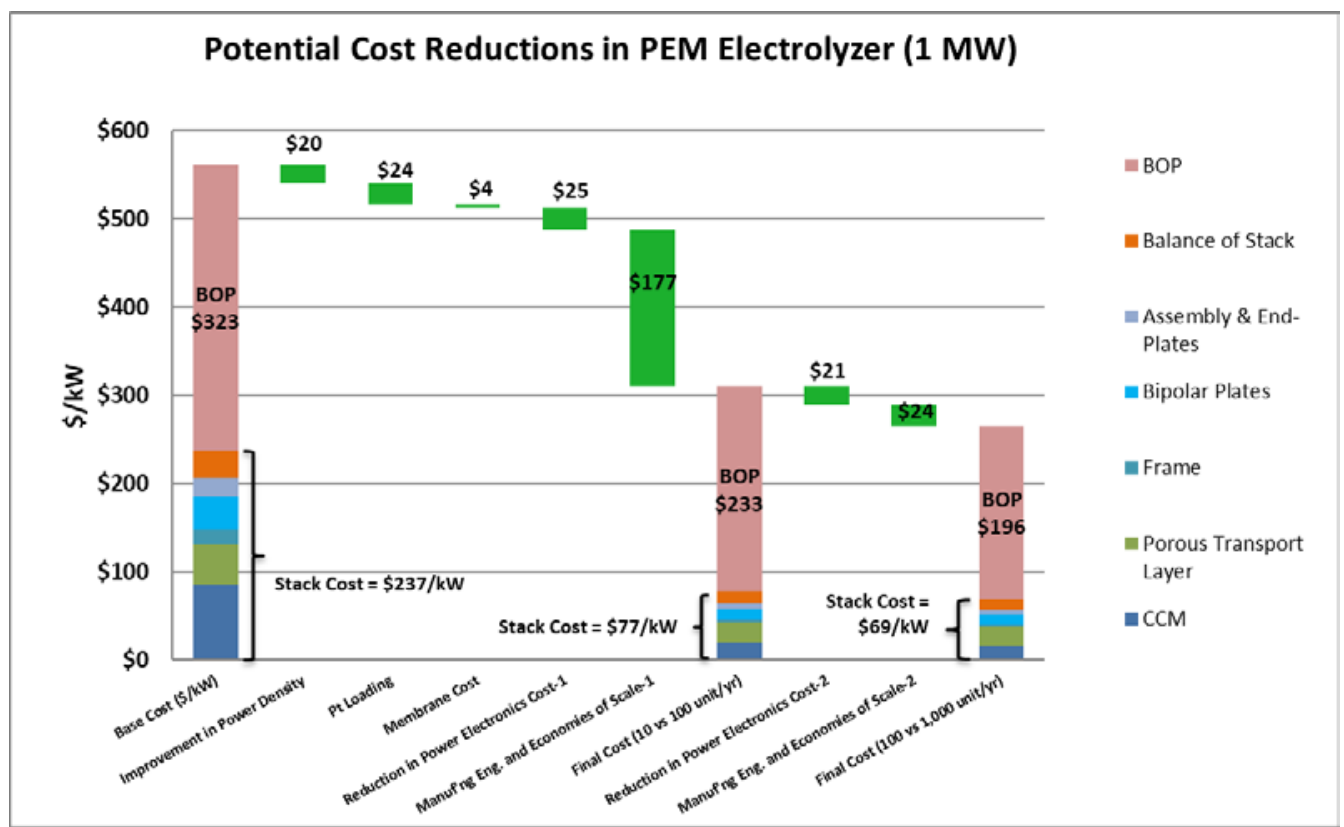

Figure ES-2. Waterfall charts showing areas where R\&D can play a role in reducing the cost of the 1-MW electrolysis system

Assumptions: improvement in power density (+20\%); Pt loading from $11 \mathrm{~g} / \mathrm{m}^{2}$ to $1 \mathrm{~g} / \mathrm{m}^{2}$, membrane cost (Nafion $117 \mathrm{vs.}$ Solvay E98-09S), and power electronics (-20\%). Economy of scale is the manufacturing cost of 10 units/yr vs. 100 units/yr vs. 1,000 units/yr. 


\section{Table of Contents}

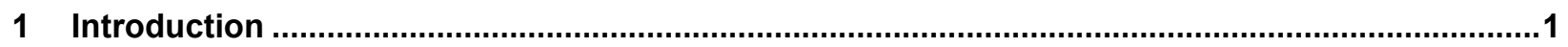

2 Electrolyzer Functional Specifications and System Design.....................................................4

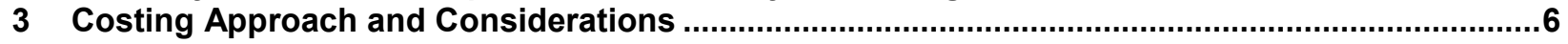



3.2 Parameters of the Manufacturing Cost Model .........................................................................



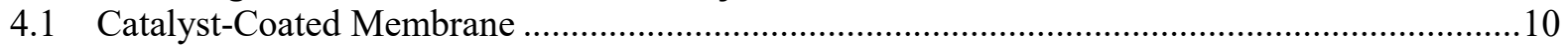

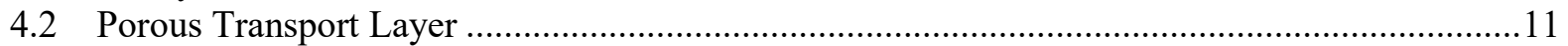

4.3 Membrane Electrode Assembly (MEA) and Frame/Seal .................................................. 12

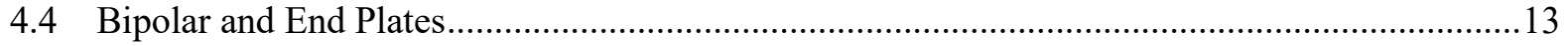



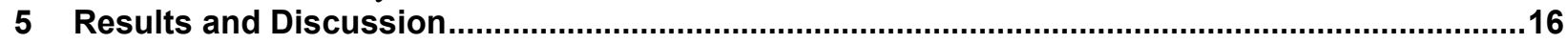

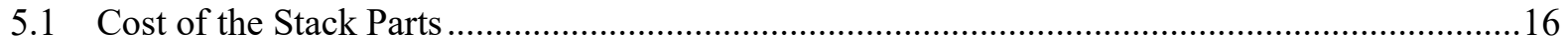



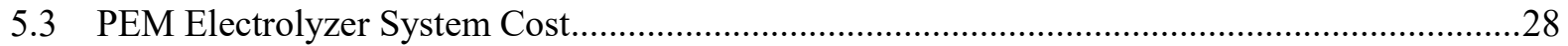

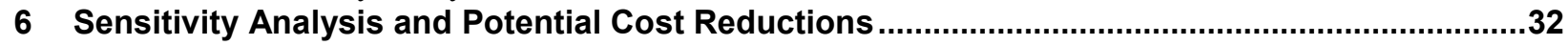



8 Effect of Electrolyzer Capital Cost on the Hydrogen Production Cost ........................................38

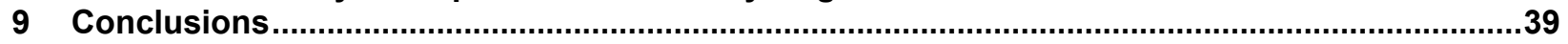

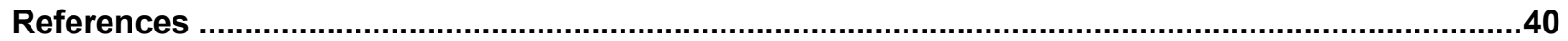




\section{List of Figures}

Figure 1. Cell repeat unit showing key components in the PEM electrolyzer - additional units would be stacked to the right and left of this repeating unit to form a PEM electrolysis stack ..............................2

Figure 2. Schematic of the PEM electrolysis system showing stack and BOP parts ...............................5

Figure 3. Process flow for catalyst deposition using spray coating ...................................................... 11

Figure 4. Process flow of the powder metallurgy process for producing titanium felts used as in the PTL12

Figure 5. Process flow for producing metal bipolar plates...............................................................13

Figure 6. Process flow for semi-automatic assembly line ............................................................ 15

Figure 7. Manufacturing cost curves for CCM made via spray coating .............................................. 18

Figure 8. Manufacturing cost curves for the titanium-based PTL ........................................................ 19

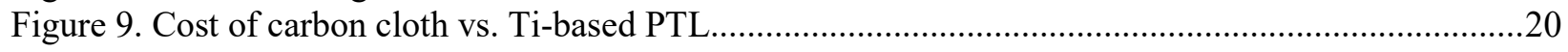

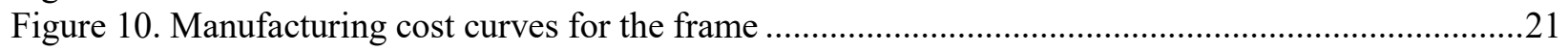

Figure 11. Manufacturing cost curves for the stamped stainless-steel plates bipolar plates ......................22

Figure 12. Manufacturing cost analysis for stack assembly process ......................................................23

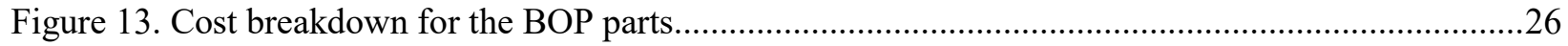

Figure 14. Manufacturing cost curve for (a) 200-kW PEM electrolyzer stack, (b) manufacturing cost curve for 1MW PEM electrolyzer stack, (c) cost breakdown for 200-kW stack, and (d) cost breakdown for 1MW stack

Figure 15. Cost curves for (a) 200-kW and (b) 1-MW electrolyzer systems showing costs of stack and BOP, and cost breakdown for (c) 200-kW and (d) 1-MW electrolyzer systems at different annual production

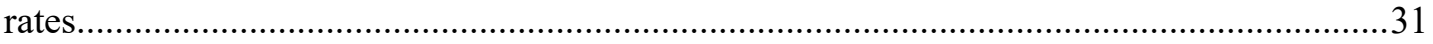

Figure 16. Impact of changing some manufacturing and cell design parameters on 200-kW PEM stack cost: (a) at 100 units/yr, and (b) at 1,000 units/yr, and 1-MW stack cost at (c) at 100 units/yr, and (d) at 1,000 units/yr. 34

Figure 17. Waterfall charts showing areas where R\&D can play a role in reducing the cost of the electrolysis

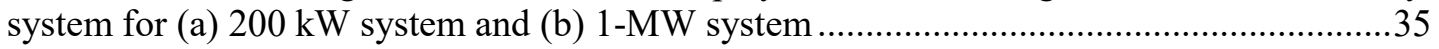

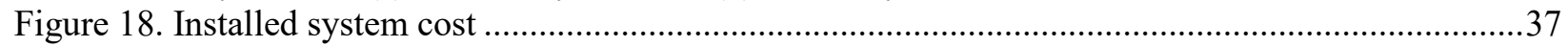

Figure 19. Effect of the capital cost, capacity factor, and electricity price on the cost of hydrogen production



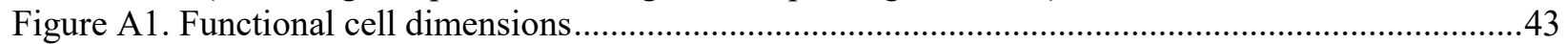

Figure A2. Example of the polarization curves for PEM electrolyzer cells .............................................44 


\section{List of Tables}

Table 1. Functional Specifications of the PEM Electrolysis System (Appendix A reports details).............4

Table 2. Scope of the Manufacturing Cost Models .......................................................................... 7

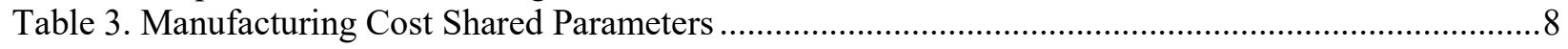

Table 4. Some Parameters Used in Developing the Cost Model for PEM Electrolyzer Stack....................10

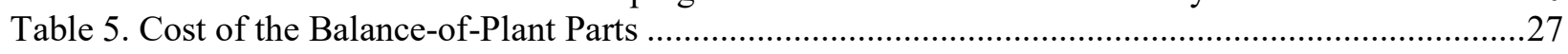

Table B.1. Cost Components and Their Mathematical Formulas …...................................................50

Table C.1. Manufacturing parameter for spray coating process of the catalyst coated membrane .............52

Table C.2. Manufacturing parameter for Powder metallurgy of the Porous Transport Layer.....................53

Table C.3. Manufacturing parameter for injection molding of the Seal/Frame ......................................54

Table C.4. Manufacturing parameter for stamped and coated bipolar plates ..........................................55

Table C.5. Manufacturing parameter for stack assembly process ........................................................56 


\section{Introduction}

Although hydrogen is abundant on the Earth in the form of water, it requires energy to split water molecules into hydrogen molecules. Hydrogen can be made by several means, including water electrolysis, hydrocarbon reforming/gasification, renewable liquid hydrocarbon reforming, and fermentation of the biomass feedstocks (AFDC n.d.).

Most of today's anthropogenic hydrogen, both internationally and in the U.S., is produced by steam methane reforming of natural gas (AFDC n.d.). The steam methane reforming process consists of two process steps. In the first step, the major component of natural gas, methane $\left(\mathrm{CH}_{4}\right)$, reacts with steam to form hydrogen and carbon monoxide. In the second step, water gas shift, carbon monoxide is reacted with steam to produce additional hydrogen and carbon dioxide (Air Products 2013). Pressure swing adsorption (PSA) technology is needed for hydrogen purification in the steam-methane reforming (SMR) process, to get high purity hydrogen suitable for fueling fuel cell electric vehicles (FCEVs). The PSA process involves the adsorption of impurities from a hydrogen rich feed gas onto a fixed bed of adsorbents at high pressure. The impurities are subsequently desorbed at low pressure into off-gas stream which results in production of an extremely pure hydrogen product (99.999\%) (Howe-Baker, 2017). Steam methane reforming systems have high production rates, and need large investment to install, which makes them suitable for central production facilities that produce tons of hydrogen every day.

Water electrolysis is the second most common method of hydrogen production. Among the challenges that face water electrolysis is the high system cost for electrolysis systems which resulted in low penetrations of PEM electrolysis technology in the markets. Three major types of electrolyzers are either currently produced commercially or could be produced commercially in the near future:

- Alkaline electrolyzers are a demonstrated water electrolysis technology at large scale, but they tend to have lower system efficiency.

- Polymer electrolyte membrane (PEM) electrolyzers work at temperatures between $50^{\circ} \mathrm{C}$ and $95^{\circ} \mathrm{C}$. PEM electrolysis is a commercial technology that could still be improved through additional R\&D.

- Solid oxide electrolyzers are still in early commercialization stage and still need more work to scale up into commercial systems.

Alkaline electrolysis is considered a mature technology and has been marketed for decades. PEM electrolysis technology, on the other hand, has positioned itself as a competitive technology, but PEM systems are still designed at lower capacities $(<1 \mathrm{MW})$ and have higher costs than alkaline electrolyzers (Schmidt et al., 2017a, Bertuccioli et al., 2014). In the U.S., Proton (NEL) and Giner and others have started to produce PEM electrolyzers because (1) manufacturing costs have decreased significantly in the last few years and (2) PEM electrolyzers tend to have higher current densities ( $\sim 5 \mathrm{X}$ of the alkaline electrolyzers) and higher efficiencies (up to $6 \%$ higher than alkaline electrolyzers (see Bertuccioli et al., 2014; Hamdan 2013; Ayers et al. 2012, Carmo et al., 2015).

A PEM electrolyzer stack consists of repeating cells that are electrically connected in series and reactant water/product gas connected in parallel (Figure 1). Thick metal plates (called end plates) 
from both ends are added to structurally hold these cells inside the stack. At the core of each of these modules is a polymer membrane with cathode and anode catalyst layers coated on the both sides of the membrane to form what is called catalyst-coated membrane (CCM). The porous transport layer (PTL) is a layer that enhances water diffusion and water splitting reaction on the surface of the membrane in the electrolysis cells. Bipolar plates, as the name suggests, have a cathodic side and an anodic side. Their main function is to separate cells in the stack, and they have channels that facilitate the transport of water, hydrogen, and oxygen inside the stack (Hamdan 2013; Ayers et al. 2012).

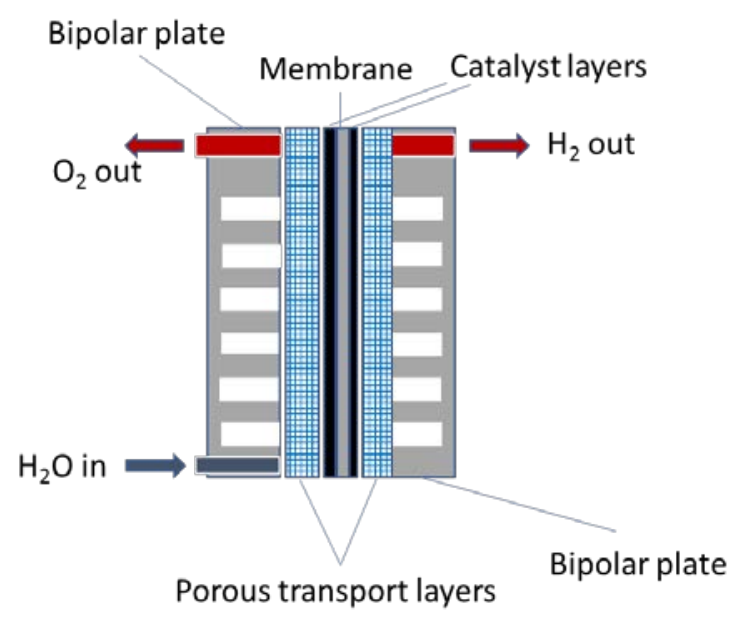

Figure 1. Cell repeat unit showing key components in the PEM electrolyzer - additional units would be stacked to the right and left of this repeating unit to form a PEM electrolysis stack

PEM electrolyzer stacks have many similar parts as PEM fuel cell stacks and-include the CCM, a gas diffusion layer, and bipolar plates. Many technoeconomic studies have revealed that significant cost reductions are possible for manufacturing these parts for fuel cells and electrolyzers with economies of scale (Contini et al. 2017; James et al. 2013; James and DeSantis 2015; Wei et al. 2014).

This document reports a detailed cost analysis of PEM electrolysis systems and identifies some potential areas where cost reductions could be targeted. The results of this work could help direct future research and development (R\&D) for the PEM electrolysis manufacturing. More specifically, the objectives of this work include to:

- Develop detailed bottom-up manufacturing cost analysis for key systems and parts in the PEM water electrolysis system

- Identify cost drivers for the PEM electrolyzer and areas for potential cost reduction areas

- Investigate effect of economies of scale and learning experience on the cost of the PEM electrolysis systems and the impact of the system cost on hydrogen production cost.

This report starts with a summary of some findings from previous technoeconomic studies on electrolyzers and fuel cells, which we used to estimate the parameters for the cell design and functional specifications for the water electrolysis system (Section 2). The report then proceeds in Section 3 to a discussion of the methods used to develop the manufacturing cost of PEM electrolyzers. Sections 4 and 5 discuss manufacturing processes used to make the key parts in the PEM stack and the expected cost associated with the manufacturing of these parts in the stack 
and the cost of the balance-of-plant (BOP) parts. Section 6 provides some sensitivity analysis for some important cell design and manufacturing parameters that could play role in reducing the cost of the PEM stack. Section 7 expands on Section 5 by reporting total system cost estimates including markup factor and installation cost. Section 8 addresses the impacts of the economies of scale electrolyzer costs and translates those capital costs to levelized costs hydrogen. 


\section{Electrolyzer Functional Specifications and System Design}

We started this cost analysis study by defining the system diagram and determining the critical cost components. Next, we used data from the literature, industry inputs, and product fact sheets for commercial PEM electrolysis systems to obtain functional and operational parameters at the stack and system levels. These functional and design parameters are often referred to as functional specifications. We then developed a bottom-up cost analysis for each of the critical stack cost components (i.e., CCM, PTL, membrane electrode assembly [MEA] frame/seal, bipolar plate, and stack assembly). Finally, we sum the individual cost curves for each stack part to calculate the overall stack cost in $\$ / \mathrm{kW}$.

Functional specifications for 200-kW and 1-MW electrolysis systems are shown in Table 1. A schematic of the PEM electrolysis system is shown in Figure 2. The stack represents the core of the system where electrochemical reactions take place. The "balance of plant" (BOP) is composed of several subsystems that provide secondary functions in the electrolyzer system. The major subsystems in the BOP and key parts in each system include:

- Power supply: AC/DC rectifier, DC voltage transducer, and DC current transducer

- Deionized water circulation system: oxygen separator tank, circulation pump, piping, valves and instrumentation, and controls

- Hydrogen processing: dryer bed, hydrogen separator, tubing, and valves and instrumentation

- Cooling: plate heat exchanger, cooling pump, valves and instrumentation, and dry cooler

- Miscellaneous: compressed air valve, ventilation and safety requirements (combustible gas detector and exhaust ventilation).

Table 1. Functional Specifications of the PEM Electrolysis System (Appendix A reports details)

\begin{tabular}{|l|r|r|c|}
\hline Parameter & \multicolumn{2}{|c|}{ Value } & Unit \\
\hline Stack power & 200 & 1,000 & $\mathrm{~kW}$ \\
\hline Gross system power & 220 & 1,100 & $\mathrm{~kW}$ \\
\hline Average hydrogen $\left(\mathrm{H}_{2}\right)$ production rate & 30 & 170 & $\mathrm{Nm} / \mathrm{hr}$ \\
\hline Average $\mathrm{H}_{2}$ production rate & 80 & 400 & $\mathrm{~kg} / \mathrm{day}$ \\
\hline Turndown ratio & $0 \%-100 \%$ & $0 \%-100 \%$ & \\
\hline Operating Pressure & $0-30$ & $\mathrm{bar}$ \\
\hline Total plate area & 957 & $\mathrm{~cm}^{2}$ \\
\hline CCM coated area & 748 & $\mathrm{~cm}^{2}$ \\
\hline Single cell active area & 680 & $\mathrm{~cm}^{2}$ \\
\hline Gross cell inactive area & 9 & $\mathrm{~A}$ \\
\hline Single cell amps & 1,156 & $\mathrm{~A} / \mathrm{cm}^{2}$ \\
\hline Current density & 1.70 & $\mathrm{~V}$ \\
\hline Reference voltage & 1.70 & $\mathrm{~W} / \mathrm{cm}^{2}$ \\
\hline Power density & 2.89 & & \\
\hline
\end{tabular}




\begin{tabular}{|l|r|r|c|}
\hline Parameter & \multicolumn{2}{|c|}{ Value } & Unit \\
\hline Platinum (Pt) loading- anode $\left(\mathrm{g} / \mathrm{m}^{2}\right)$ & \multicolumn{2}{|c|}{7.0} & $\mathrm{~g} / \mathrm{m}^{2}$ \\
\hline Platinum-iridium loading- cathode $\left(\mathrm{g} / \mathrm{m}^{2}\right)$ & \multicolumn{2}{|c|}{4.0} & $\mathrm{~g} / \mathrm{m}^{2}$ \\
\hline Single cell power & \multicolumn{2}{|c|}{1,965} & $\mathrm{~W}$ \\
\hline Cells per system & 102 & 510 & cells \\
\hline Stacks per system & 1 & 2 & stacks \\
\hline Cells per stack & 102 & 255 & $\mathrm{cells}$ \\
\hline Water pump & 5 & 25 & $\mathrm{~kW}$ \\
\hline Other paras. Loads & 15 & 75 & $\mathrm{~kW}$ \\
\hline Parasitic loss & 20 & 100 & $\mathrm{~kW}$ \\
\hline
\end{tabular}

Values in italic are parasitic losses in the balance of plant (BOP) and represent average values from several sources.

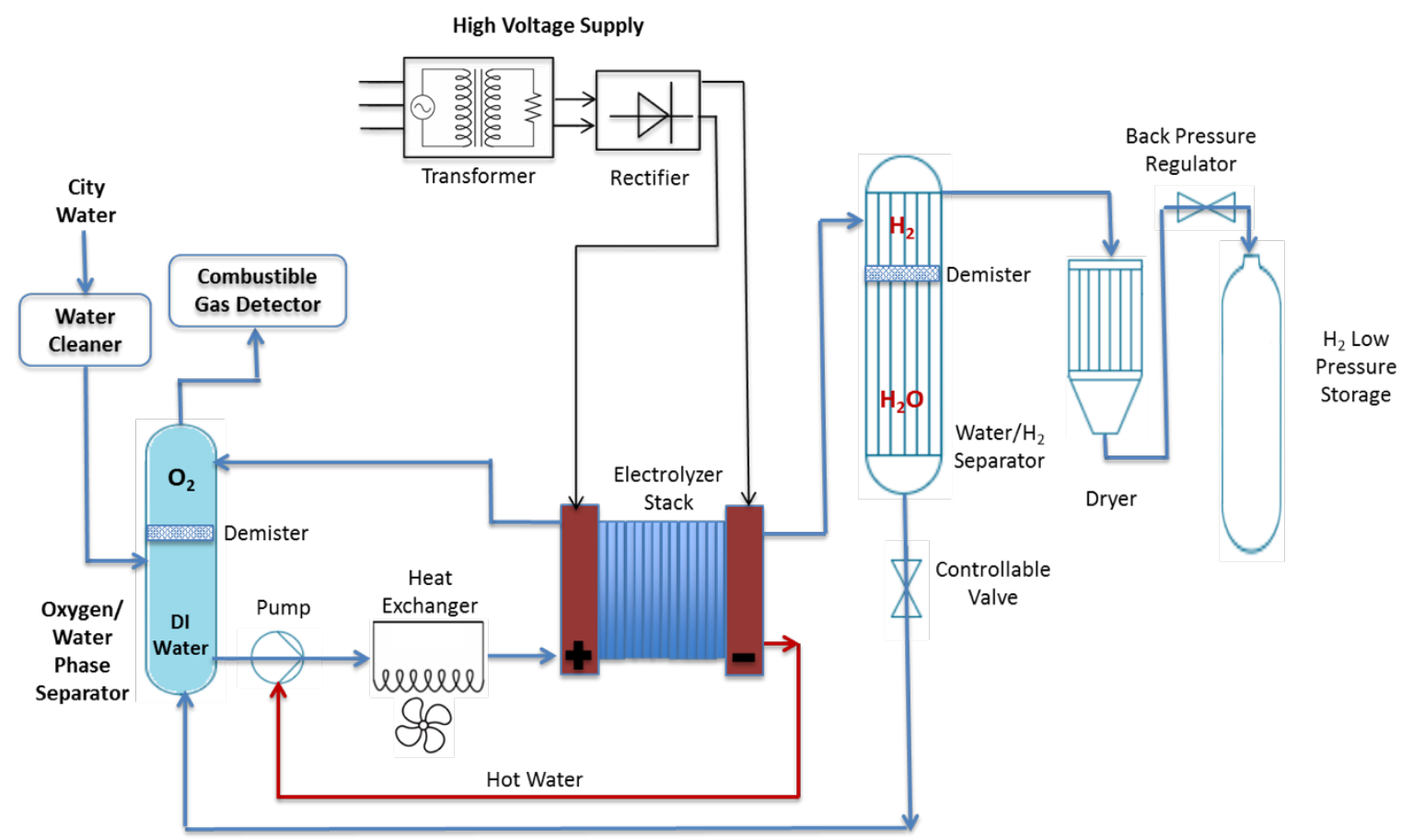

Figure 2. Schematic of the PEM electrolysis system showing stack and BOP parts 


\section{Costing Approach and Considerations}

This section describes the overall costing approach and the underlying assumptions used in developing cost models. Several cost components are included in the direct manufacturing cost model to account for all cost incurred in the final products. These cost components include material, labor, capital, energy, maintenance, facility/building, and scrap costs. These components represent direct manufacturing cost, excluding research and development cost, sales, general and administration cost, warranty cost or debt service cost. However, all these indirect cost components are combined in the markup factor, which was assumed to be $50 \%$ of the total direct manufacturing cost (James and DeSantis 2015; Saggiorato et al. 2017).

Bottom up manufacturing cost models were developed for several parts in the stack:

- $\quad$ Catalyst coated membrane (CCM)

- Porous transport layer (PTL)

- Seal/Frame

- Bipolar plates

- Stack assembly and end plates

Cost values for BOP parts were collected from quotes we received from part suppliers for the critical parts in the BOP and estimates in the literature for general purpose parts such as piping, pressure gauges, valves, water pumps, and other parts. Assembly and testing are the main manufacturing processes that take place in assembling BOP parts within the system. The direct cost of BOP parts and their assembly and testing costs are then added to the direct manufacturing cost using bottom-up approach for the stack modules to estimate the final electrolyzer system cost.

A make-or-buy decision is based on whether the part is readily available as a commodity item, if it is an off-the-shelf part, or if it is a special manufactured part that necessitates certain design and manufacturing routes, or if the parts are associated with proprietary manufacturing processes (e.g., Nafion membrane ${ }^{1}$ ). If the product falls outside the scope of the regular business that electrolyzer manufacturers do (e.g., manufacture pumps, valves, tubes, and electronic components), the decision was made to outsource these parts from suppliers and include the price in the BOP cost analysis. In this analysis, BOP components are all assumed to be outsourced from part vendors, while key stack parts are assumed to be largely manufactured inhouse.

\subsection{Modeling Approach}

This section describes the direct manufacturing cost modeling approach developed for the PEM electrolyzer stack components and the cost analysis of the balance of plant (BOP). The first step in the bottom-up costing analysis is to define the electrolyzer system configuration and key

\footnotetext{
${ }^{1}$ Nafion is a registered trademark of DuPont.
} 
subsystems in it. Next, literature reviews and industry inputs are used to obtain functional and operational stack and system parameters (also known as functional specifications). The system configuration and functional specifications are then used to define the system size, key subsystems and system components, and stack and system performance specifications. Then, we use these specifications and system functional parameters to develop the direct manufacturing cost model (Wei et al., 2014).

The direct manufacturing cost analysis uses activity-based costing for the major manufacturing processes required to make the key components in the PEM stack. A machine rate that corresponds to annual production rates is computed and broken down by cost components that cover capital, facilities, energy, and maintenance costs. To obtain the process cost per module/part, one can multiply machine rates expressed in dollars per hours $(\$ / \mathrm{hr})$ by the total time required to finish each part or batch of parts. Normalized manufacturing cost per part (\$/piece) is calculated by dividing machine rate $(\$ / \mathrm{hr})$ over line throughput (piece/hr). Labor and material costs are added to the normalized part cost $(\$ /$ piece $)$ to calculate the final part cost in (\$/piece). Overall manufacturing costs are then calculated as the sum of all modules or cost components normalized to the annual production rates in units per year ${ }^{2}$.

Several cost components are included in the direct manufacturing cost model to account for all cost incurred in the final products. These cost components include material, labor, capital, energy, maintenance, facility, and scrap costs. And, these components represent direct manufacturing cost, excluding any research and development cost, sales, general and administration cost, warranty cost or debt service cost. However, all these indirect cost components are combined in the markup factor (Saggiorato et al. 2017). Table 2 summarizes direct and indirect manufacturing cost components.

Table 2. Scope of the Manufacturing Cost Models

\begin{tabular}{|l|l|}
\hline Direct Manufacturing Cost & Indirect Manufacturing Cost \\
\hline Capital costs & Research and development costs \\
Facilities/building costs & General and administration costs \\
Materials costs & Sales and marketing costs \\
Scrap costs (yield losses) & Product warranty costs \\
Labor costs & Debt service costs \\
Energy costs & Transportation costs \\
Maintenance costs & \\
\hline
\end{tabular}

Appendix B contains detailed economic calculations and the mathematical formulas used in the bottom-up manufacturing cost analysis (both direct and indirect manufacturing cost models).

The electrolysis system is made up of the stack and other subsystems needed to ensure full functionality of the electrolysis process from water supply at one end to hydrogen storage at the other end of the system. These subsystems are bundled in the BOP. Cost values for BOP parts were collected from the direct quotes we received from part suppliers and estimates in the

2 Units here refer to number of electrolyzers produced per annum 
literature for general purpose parts such as piping, pressure gauges, valves, water pumps, and other parts. The direct cost of BOP parts and their assembly and testing costs are then added to the direct manufacturing cost for the stack parts to estimate the final electrolyzer system cost.

\subsection{Parameters of the Manufacturing Cost Model}

To facilitate a better understanding of cost drivers and their role in determining final product cost, we collected data from multiple sources, including previous studies, patents, technical reports, and data sheets for commercial electrolyzer systems. We then used the collected data to develop assumptions for different manufacturing process studies in this analysis. Key parameters used in developing the cost model are summarized in Table 3. Worth mentioning that the base year for the cost analysis is 2015 , so all cost values are expressed in 2015 dollars. Economic calculations are discussed in Appendix B.

Table 3. Manufacturing Cost Shared Parameters for U.S. based manufacturing facility

\begin{tabular}{|c|c|c|c|c|}
\hline Parameter & Symbol & Value & Units & Notes/Sources \\
\hline Operating hours & $t_{h s}$ & vary & hours & 8-hour base shift, 2 shifts per day \\
\hline Annual operating days & $t_{d y}$ & 250 & days & $\begin{array}{l}52 \text { weeks/yr, } 5 \text { working days per week, } \\
10 \text { holidays/yr }\end{array}$ \\
\hline Average inflation rate & $j$ & $2.6 \%$ & & World Bank data ${ }^{a}$ \\
\hline Discount rate & $j_{d}$ & $10 \%$ & & From James et al., (2015) \\
\hline Corporate income tax & $i_{i}$ & $40 \%$ & & Tax Foundation ${ }^{b}$; for profitable income only \\
\hline Property tax & $i_{p}$ & $1.4 \%$ & & New York Times ${ }^{c}$ \\
\hline End-of-life salvage value & $k_{e o l}$ & $2 \%$ & & assume $2 \%$ of the original equipment value \\
\hline Tool lifetime & $T_{t}$ & 15 & years & typical value in practice \\
\hline Energy tax credits & ITC & 0 & dollars & \\
\hline Energy cost & $c_{e}$ & 0.1 & $\$ / k W h_{e}$ & \\
\hline Floor space Cost & $c_{f s}$ & 880 & $\$ / m^{2}$ & average for factory $^{d}$ \\
\hline Building depreciation & $j_{b r}$ & 0.031 & & U.S. Bureau of Economic Analysis rates ${ }^{e}$ \\
\hline Building recovery & $T_{b r}$ & 31 & years & U.S. Bureau of Economic Analysis rates ${ }^{e}$ \\
\hline Building footprint & $a_{b r}$ & varies & $\mathrm{m}^{2}$ & \\
\hline Hourly labor cost & $c_{\text {labor }}$ & 23.63 & $\$ / \mathrm{hr}$ & hourly wage per worker \\
\hline
\end{tabular}

a "Inflation, GDP Deflator (Annual \%)" The World Bank., https://data.worldbank.org/indicator/ny.gdp.defl.kd.zg

b Pomerleau 2014

c "State-by-State Property-Tax Rates," New York Times, April 10, 2007, https://www.nytimes.com/2007/04/10/business/11leonhardtavgproptaxrates.html

d See for example, Turner and Townsend n.d. (http://www.turnerandtownsend.com/ICC Survey Brochure final 6MGJa.pdf.file) and CBRE n.d. (http://www.cbre.us/services/projectmanagement/AssetLibrary/EMEA\%20Fit Out Cost Guide 2014.pdf) e BEA n.d. 
The annualized cost in $\$$ yr (excluding variable cost components: materials and labor) was adopted from the economic model developed by Haberl (1993):

$$
C_{y}=C_{c}+C_{r}+C_{o c}+C_{p}+C_{b r}+C_{i}+C_{m}-C_{s}-C_{i n t}-C_{d e p}
$$

where:

$\mathrm{C}_{\mathrm{y}}$ is the total annualized cost.

$\mathrm{C}_{\mathrm{c}}$ is the annualized capital/system cost (with interest).

$\mathrm{C}_{\mathrm{r}}$ is the replacements or disposal cost.

$\mathrm{C}_{\mathrm{oc}}$ is the operating cost (e.g., electricity), excluding labor.

$\mathrm{C}_{\mathrm{p}}$ is the property tax cost.

$\mathrm{C}_{\mathrm{br}}$ is the building or floor space cost.

$\mathrm{C}_{\mathrm{i}}$ is the tool insurance cost.

$\mathrm{C}_{\mathrm{m}}$ is the maintenance cost.

$\mathrm{C}_{\mathrm{s}}$ is the end-of-life salvage value.

$\mathrm{C}_{\text {int }}$ is the deduction from income tax.

$\mathrm{C}_{\mathrm{dep}}$ is the deduction due to tool depreciation.

In addition to the annualized overhead cost components shown above, we also added the following cost components to get the complete direct manufacturing cost:

- Labor cost is estimated using hourly paid workers to make a certain number of units per year.

- Materials cost (including scrap cost) is based on the materials required to make certain products (e.g., costs of stainless-steel sheets and coating materials used in bipolar plates).

All values are adjusted to 2015 dollars. In the current version of the model, $C_{r}$ (the replacement or disposal cost) and $\mathrm{C}_{\mathbf{i}}$ (the tool insurance cost) are assumed to be zero. In this analysis, we assumed the manufacturing facility would be constructed solely to manufacture a certain type of products (e.g., coating of the catalyst layers in the CCM and production of PTL). We also assumed investors would start from scratch (i.e., they would build the facility and acquire new equipment to run the facility and would then hire people to work in the plant). This latter assumption led to another assumption where we assumed no net income for the new manufacturing facility; thus, income tax credits such as interest tax credits do not factor into the final cost calculations. 


\section{Manufacturing Cost Model for PEM Electrolyzer}

Manufacturing cost models were developed for the key parts in the stack, including the CCM, PTL, bipolar plate, seal and frame, and end plates with the required assembly process to assemble these components into the stack. Table 4 summarizes the main manufacturing processes along with some key parameters used in developing cost models for these stack parts. Other important manufacturing process parameters for all manufacturing routes investigated in this study are shown in Appendix C.

Table 4. Some Parameters Used in Developing the Cost Model for PEM Electrolyzer Stack

\begin{tabular}{|l|l|l|}
\hline Part & Assumptions & Notes \\
\hline Membrane & Nafion 117 (purchased part) & $\begin{array}{l}\text { Alternatives include PFSA (PEEK, PBI) } \\
\text { membranes }^{\text {a }}\end{array}$ \\
\hline Pt & Pt-price $=1,500 /$ tr.oz ${ }^{\mathrm{b}}$ & $\begin{array}{l}\text { U.S. Department of Energy (DOE) } \\
\text { current value }\end{array}$ \\
\hline PTL & $\begin{array}{l}\text { Platinum loadings: } \\
\text { Anode: } 7 \mathrm{~g} / \mathrm{m}^{2}(\mathrm{Pt}) \\
\text { Cathode: } 4 \mathrm{~g} / \mathrm{m}^{2}(\mathrm{Pt}-\mathrm{Ir})\end{array}$ & $\begin{array}{l}\text { Spray coating (alternative processes } \\
\text { include slot-die coating and screen } \\
\text { printing) }\end{array}$ \\
\hline Frame & $\begin{array}{l}\text { Sintered porous titanium }(\text { anode side) } \\
\text { Caron paper (cathode side) } \\
\text { Titanium powder price }=\$ 35 / \mathrm{kg}\end{array}$ & $\begin{array}{l}\text { Ti-PTL Porosity=30\%; Ti-PTL coated with } \\
\text { gold }(100 \text { nm) } \\
\text { Carbon cloth: Toray Paper 090 }- \text { TGP-H- } \\
090 \text { (thickness }=280 ~ \mu \mathrm{m})\end{array}$ \\
\hline Plates & $\begin{array}{l}\text { PPS-40GF or PEEK thermoplastics } \\
\text { Thickness=5 mm }\end{array}$ & $\begin{array}{l}0.625 \mathrm{~cm} \text { from each side of the CCM was } \\
\text { used for MEA frame bonding (injection } \\
\text { molding) } \\
\text { Total frame width }=2.445 \mathrm{~cm}\end{array}$ \\
\hline
\end{tabular}

a PFSA = perfluorosulfonic acid, PEEK = polyetheretherketone, $\mathrm{PBI}$ = polybenzimidazole, $\mathrm{PPS}-40 \mathrm{GF}$ : polyphenylene sulfide with $40 \%$ glass fiber filler

${ }^{\mathrm{b}}$ tr.oz: troy ounce $=31.103477$ grams

\subsection{Catalyst-Coated Membrane}

The catalyst-coated membrane (CCM) is made by depositing catalyst layers (platinum group metals) on each side of the Nafion membrane to form the cathode and anode layers. The anode side of the selective polymer membrane is where splitting of the water molecules takes place to make oxygen molecules, protons, and electrons. After this happens, the protons pass through the membrane and combine with electrons delivered through an external circuit to produce hydrogen molecules. Nafion is a perfluorosulfonic acid-based (PFSA) polymer. PFSA polymers have characteristics (e.g., high conductivity, high chemical stability) that make it the preferred membrane technology for use in PEM stacks.

Current catalyst deposition methods include spray coating and screen printing. Emerging coating technologies such as the slot-die and doctor blade coatings (forms of roll-to-roll manufacturing processes) can increase the speed of coating process and improve the quality of the coated CCM 
parts. In this cost analysis, we used spray coating as the base of the analysis. Figure 3 shows a schematic of the spray coating process with the quality control unit that uses optical and/or infrared scanning systems. This process starts by unrolling the Nafion membrane sheet. Then the Nafion membrane is coated using precise spraying nozzles to deposit platinum group metal on the surface of the membrane, e.g., the anode side first. After that, the wet membrane is dried and cooled down, then it undergoes into a second coating process where the other side of the membrane is coated (cathode side) to obtain the dried catalyst coated membrane (CCM). The final CCM is then cut into smaller individual pieces to be used in the MEAs.

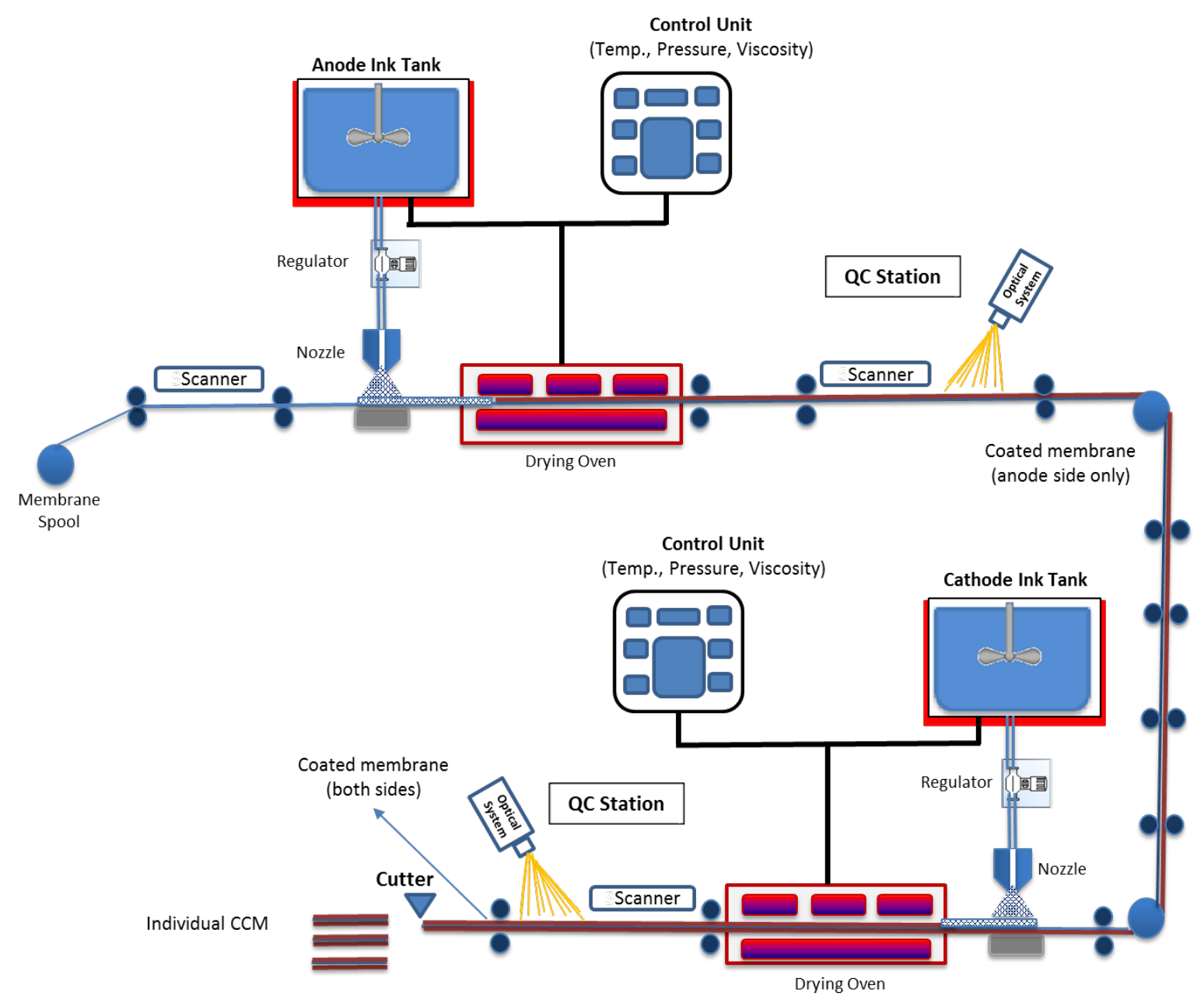

Figure 3. Process flow for catalyst deposition using spray coating

$$
\mathrm{QC}=\text { quality control }
$$

\subsection{Porous Transport Layer}

The corrosive environment inside the PEM stack may limit the type of materials that can be used in the PTL, which is also called the gas diffusion layer in the literature. The PTL should possess certain characteristics (e.g., good corrosion resistance) and certain porosity to facilitate the transport and diffusion of the gases and fluids inside the MEA. 
The PTL can be made from sintered titanium via powder metallurgy or from carbon cloth with a certain thickness. ${ }^{3}$ In this study, we assumed anode PTL is made from titanium powder via the powder metallurgy process, while the cathode PTL is made from carbon cloth. The process flow for manufacturing of titanium-felts used in the PTL is shown in Figure 4. This process starts by mixing titanium powder with small amounts of adhesive powder and lubricants to facilitate compaction of the brittle titanium particles. The "green" compacts coming from the compaction process are then placed in the sintering furnace, where sintering (partial melting process) takes place under controlled conditions (e.g., temperature, oxygen level, and cooling time). Parts coming out of the furnace need minor cleaning or machining to get the final titanium felts, which are sent to the coating station where they are coated with a precious material (gold or platinum) to reduce the contact resistance and reduce oxidation (Lettenmeier et al., 2017). The powder metallurgy process is versatile process that offers several advantages such as the ability to compact several parts in one shot and the ability to adjust the compaction pressure to get the desired porosity in the PTL; in this analysis, porosity was assumed to be $30 \%$ by volume. Manufacturing process parameters for powder metallurgy and coating processes are summarized in Appendix C.
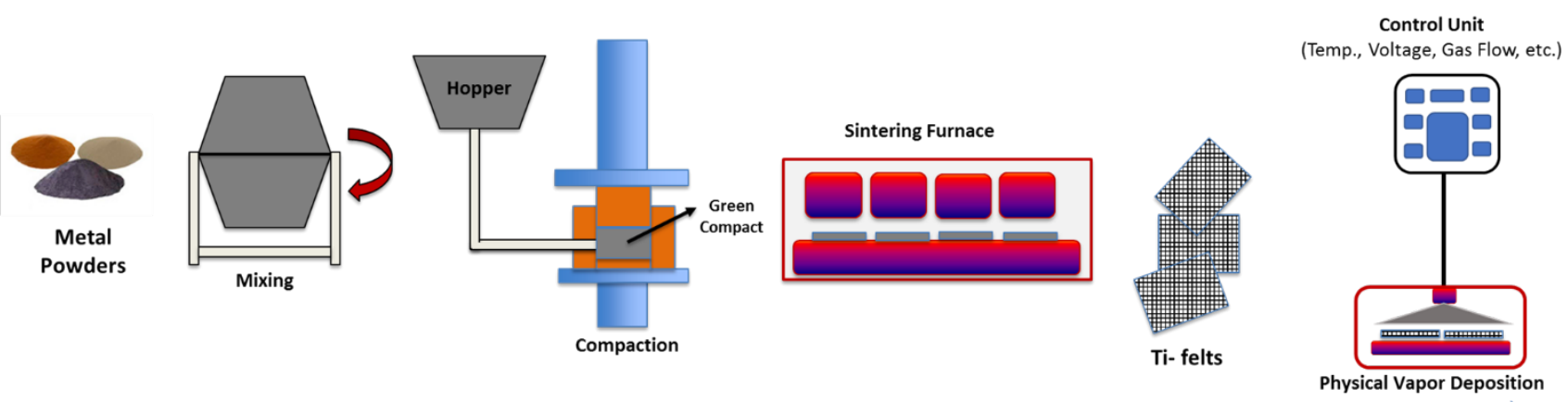

Figure 4. Process flow of the powder metallurgy process for producing titanium felts used as in the PTL

\subsection{Membrane Electrode Assembly (MEA) and Frame/Seal}

CCM and PTL together represent the MEA. Parts in the MEA are held together by the frame, which is made from polyphenylene sulfide (PPS) resin mixed with $40 \%$ glass fiber. The width of the frame is $4.9 \mathrm{~cm}$ from each side of the MEA. The PPS-based frame provides the flexibility required to hold the MEA and the durability to withstand the high operating temperature $\left(50^{\circ} \mathrm{C}-\right.$ $120^{\circ} \mathrm{C}$ ) and the corrosive environment inside the stack. Injection molding was assumed to be the base process in this analysis. Manufacturing process parameters for an injection molding production line are summarized in Appendix C.

\footnotetext{
${ }^{3} \mathrm{~A}$ common carbon cloth used in PEM electrolyzers and fuel cells is Toray Paper 090 - TGP-H-090 (thickness $=280 \mu \mathrm{m}$ ), which is a carbon fiber composite sheet suitable for use as a catalyst backing layer in the PEM electrolyzer stack.
} 


\subsection{Bipolar and End Plates}

Bipolar plates can be made from several materials, including metals with good corrosion resistance such as stainless steel or from carbon composites made through injection molding or powder metallurgy (Wei et al. 2014). In this study, we assumed a stamped stainless-steel plate (thickness $=5 \mathrm{~mm}$ ) that is coated with a very thin gold layer $(100 \mathrm{~nm})$ to improve its corrosion resistance and surface finish.

As shown in Figure 5, the process for producing metal bipolar plates starts by making stainless steel blanks from the received coils. Then, the required channels are created on both sides of the sheet using a stamping die. After that, the stamped parts are cleaned in a chemical bath to remove dirt and grease, and they are then inserted into the physical vapor deposition machine. Temperature and voltage are then adjusted to create the required environment for gold to vaporize and bombard the plate surface to make a very thin gold layer. This coating process produces better corrosion resistance parts and improves the durability of the stainless-steel plates (Kumar at al., 2010; Yoon et al., 2008).

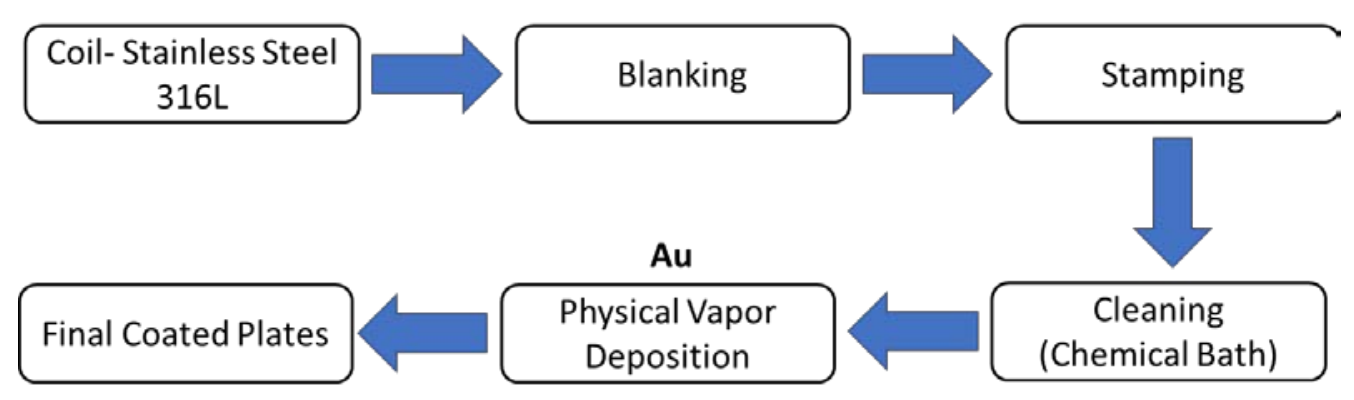

Figure 5. Process flow for producing metal bipolar plates

\subsection{Stack Assembly}

Most of the electrolyzer stack assembly lines today rely less on automated operations than manual ones, where workers stack, align, and connect the components to produce an electrolyzer stack. However, electrolyzer manufacturers can replicate battery assembly line automation in the fuel cell and electrolyzer assembly lines by investing in increasing the level of automation and adding more robots to the assembly line. And, investing in automation should be linked to the expected benefits (cost, time, and quality), so any investment in the automation level for assembly line should be justified at least by the production volumes and payback periods. In this study, we assumed three different levels of automation in the stack assembly line that correspond to the annual production volume. We assumed a manual assembly line for the low production volumes $(<100 \mathrm{k} \mathrm{MEAs} / \mathrm{yr})$, where most of the assembly steps are made manually by skilled workers. A semi-automated assembly line was assumed for medium production volumes (100,000-700,000 MEAs/yr), and a fully automated assembly line was assumed for high production volumes (>700k MEAs/yr). 
The stack assembly process in the semi-automatic stack assembly line is shown in Figure 6. This line combines the framed MEAs with the bipolar plates and assembles them in the electrolyzer stack. The proposed numbers of annual MEAs and level of automation were validated by our industrial collaborators. In the automated case, a robotic feed of plates is followed by screen printing or injection molding of the gaskets and UV curing steps. The plate/MEA are then stacked and gently compressed to add the compression bands or tie rods to hold the stack parts together and decrease the gaps between parts before proceeding to the next step, where balanceof-stack parts are added to the system. In the last step, the stack undergoes multiple stages of conditioning and testing. 


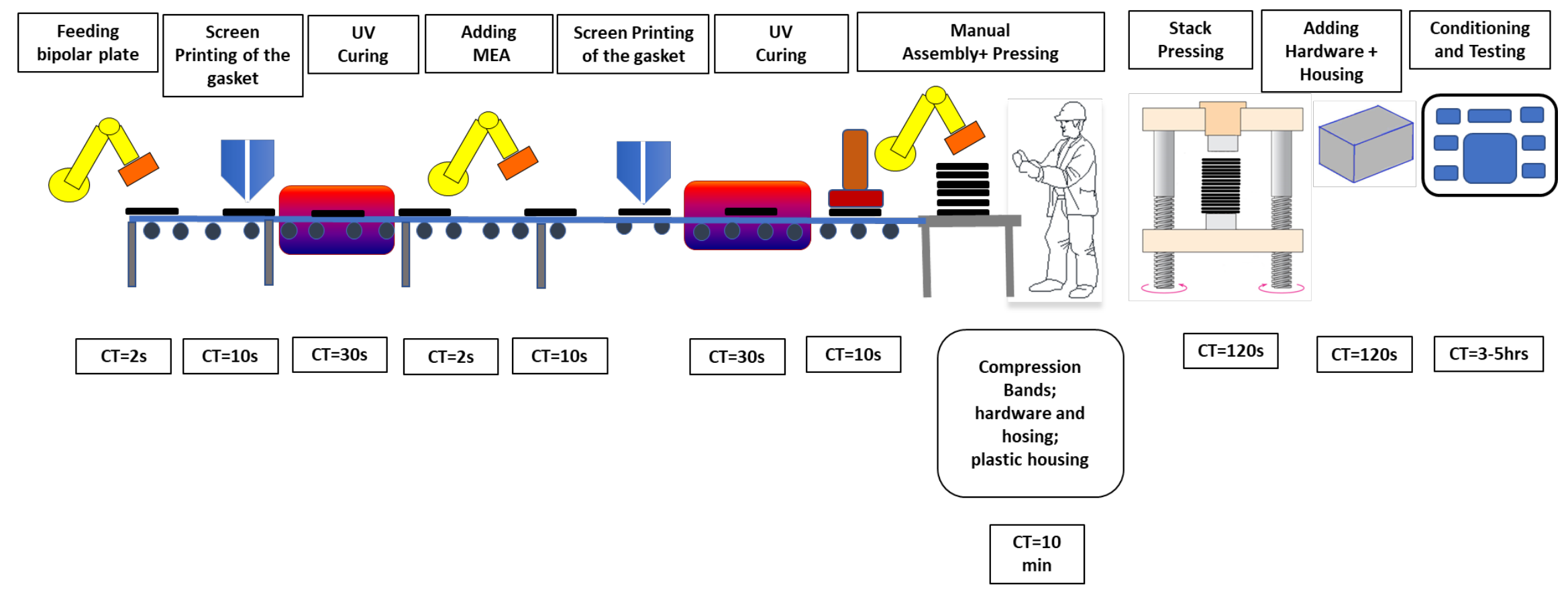

Figure 6. Process flow for semi-automatic assembly line

$\mathrm{CT}=$ cycle time 


\section{Results and Discussion}

\subsection{Cost of the Stack Parts}

The manufacturing cost per produced item is typically high at low-production volumes and therefore some manufacturers may find it more economic to outsource some of these parts rather than produce them in-house. However, this analysis assumed all stack components-except those specifically mentioned in Section 4 - are manufactured in-house. In this section, we discuss individual component cost breakdowns in natural units (e.g., $\$ / \mathrm{m}^{2}$ for the CCM or $\$ /$ piece for the plate) and normalized units in $\$ / \mathrm{kW}$ for $200-\mathrm{kW}$ and 1-MW PEM electrolysis systems; these system sizes were selected as baselines for small and large size (MW-scale) electrolysis systems respectively

Figure 7 shows the cost curves for CCM made via spray coating in $\$ / \mathrm{m}^{2}$ and for the total stack cost in $\$ / \mathrm{kW}$. Economies of scale have greater impact on the overall cost because the capital and building costs are divided over more units. In many cases, cost curves for the individual stack part and for the whole stack start to flatten out (i.e., be less steep) at annual production rates of 1,000 units per year or more. For both 200-kW and 1-MW systems, CCM cost is dominated by the Nafion membrane and precious metal (Pt and Ir used in the catalyst layers) which are mixed with Nafion ionomer and other solvents to make the catalyst ink.

When we look at the cost curve for the PTL (Figure 8), we see that material cost starts to dominate at production rates of 100 units/yr or more for the $200-\mathrm{kW}$ electrolyzer and 20 units/yr or more for the 1-MW system. The cost of titanium powder is still much lower than that of precious materials ( $\mathrm{Pt}$ and $\mathrm{Ir}$ ) and the expensive membrane used in the CCM. The expensive coating material (gold) also adds extra cost to the Ti-based PTL. Contributions of the overhead cost (building and capital costs) start to decrease at higher production rates because of the impact of economies of scale. A comparison between Ti-based and carbon cloth- based PTL is shown in Figure 9, which shows that Ti-based PTL from both sides could be competitive at higher production rates. Purchased carbon cloth seems to be cheaper and suitable to be used in the cathode side of the MEAs. Carbon cloth (cathode) and Ti-based PTL (anode) are assumed as a base case in this study.

Cost curves for the MEA frame made by injection molding process is shown in Figure 10. We can see that capital and building cost dominate at most annual production rates. Cost curves for stamped and coated bipolar plates show that materials dominate the cost at high production rates, leaving less than $10 \%$ of the total cost for other cost contributors starting at 1,000 units/yr or more (Figure 11). Labor cost here is nominal because of the underlying assumption that we need small labor-hours per piece because the blanking and stamping processes are batch processes where several pieces can be produced at one time, and many units can be inserted in one batch in the physical vapor deposition machine.

For stack assembly process cost analysis, we used normalized units $(\$ / \mathrm{kW})$ because unlike other parts in the stack, there is no clear natural unit to allocate stack assembly cost to. The manufacturing cost chart for stack assembly is shown in Figure 12, which reveals that the biggest contributor in the stack assembly is the labor cost at the low production rates where the manual assembly line is used to assemble the stacks. Semiautomated and fully automated assembly lines 
may be needed for production volumes that exceed 1,000 stacks per year. Direct material cost here includes the cost of the stainless-steel end plates and compression bands.

The cost breakdown in Figure 12c for the $200 \mathrm{~kW}$ system shows sort of a sharp change in the capital cost contribution between 100 systems/yr and 1,000 systems/yr. The cause of the change comes from the change from the manual assembly line to semi-automated assembly line which occurs at an annual production rate of 1,000 system/yr (equivalent to 102,000 MEAs), and another change to a fully-automated line occurs at 10,000 systems/yr (equivalent to 1,020,000 MEAs). Similarly, for the $1 \mathrm{MW}$ stack (Figure 12d) we switched from manual assembly line to semi-automated line at annual production rate of 1,000 system/yr (equivalent to 509,000 MEAs). Another change from semi-automated to fully automated assembly line takes place at annual production rate of 2,000 system/yr (equivalent to 1,018,000 MEAs).

Balance of stack cost covers the cost of some parts (e.g., stack housing, manifolds, wires, insulation material, compression bands, etc.). The cost of balance of the stack is assumed to be $13 \%$ of the total stack cost. This estimate is based on average values from other cost studies (see for example Ayers, 2016, Ayers et al., 2015) 


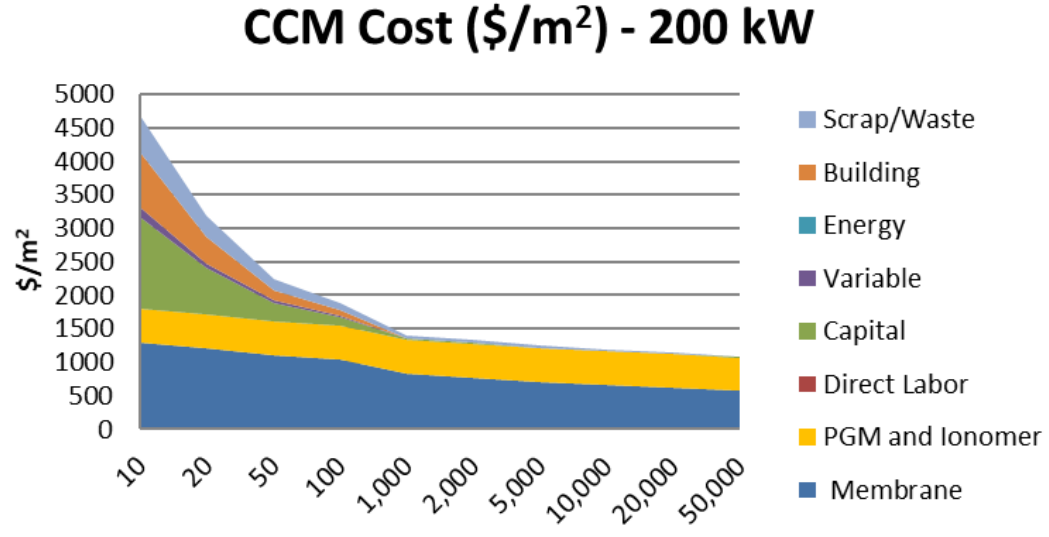

Annual Production Rate (unit/yr)

(a)

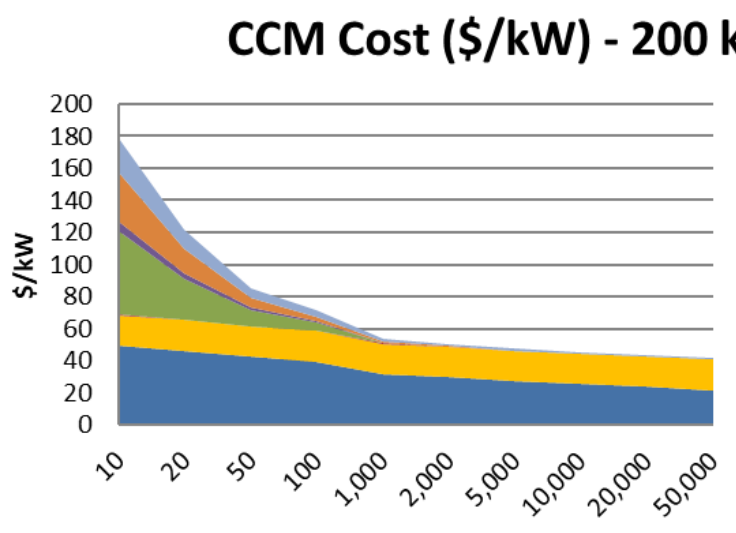

Annual Production Rate (unit/yr)

- Scrap/Waste
— Building
— Energy
- Variable
- Capital
- Direct Labor
- PGM and lonomer
- Membrane

- Membrane

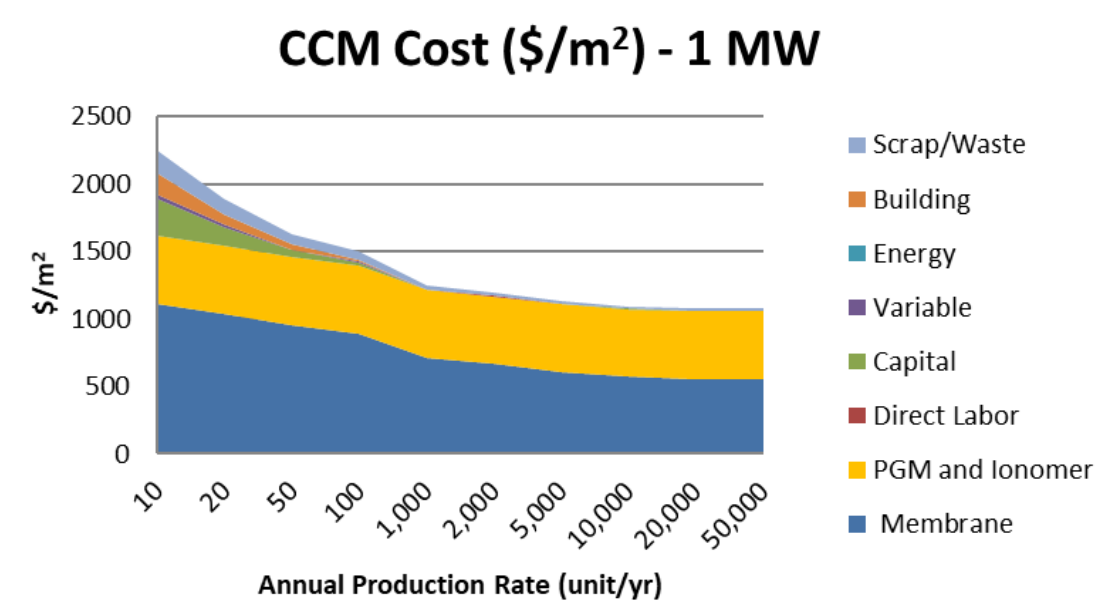

(b)

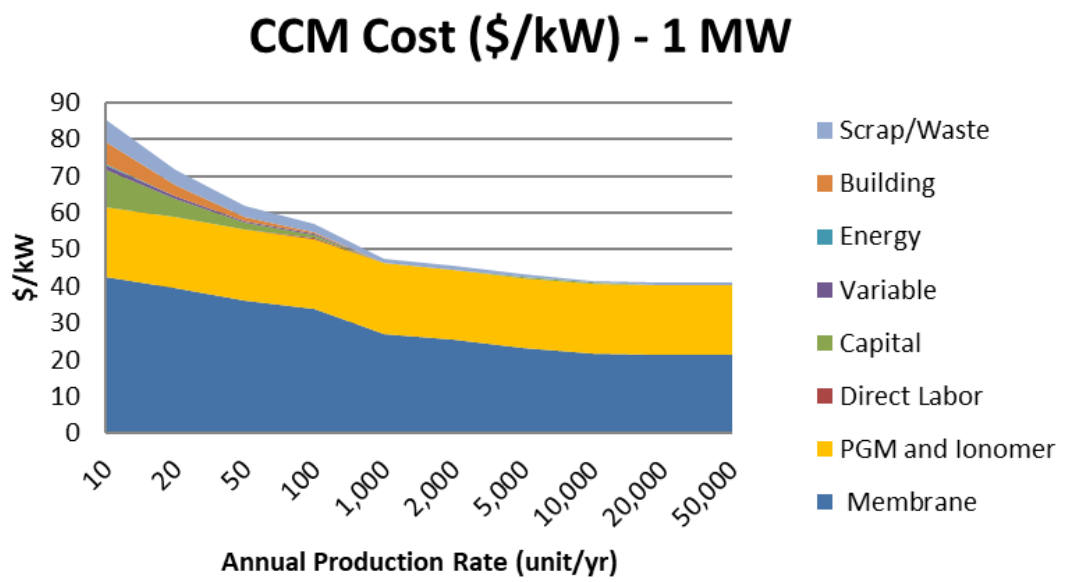

Annual Production Rate (unit/yr)

(c)

Figure 7. Manufacturing cost curves for CCM made via spray coating in (a) CCM cost for $200-\mathrm{kW}$ system in $\$ / \mathrm{m}^{2}$, (b) CCM cost for 200-kW system $\$ / \mathrm{kW}$, (c) CCM cost for $1-M W$ system in $\$ / \mathrm{m}^{2}$, and (d) CCM cost for $1-\mathrm{MW}$ system in $\$ / \mathrm{kW}$

Annual production rate is the number of systems produced in one year. 
PTL cost (\$/pcs) - 200 kW system

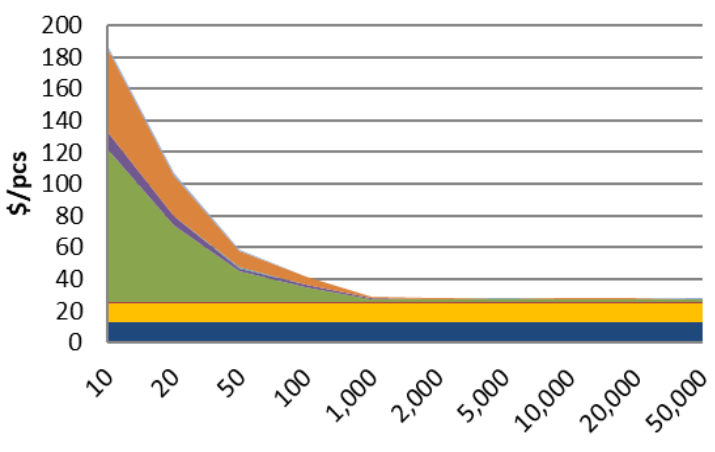

Annual Production Rate (unit/yr)

(a)

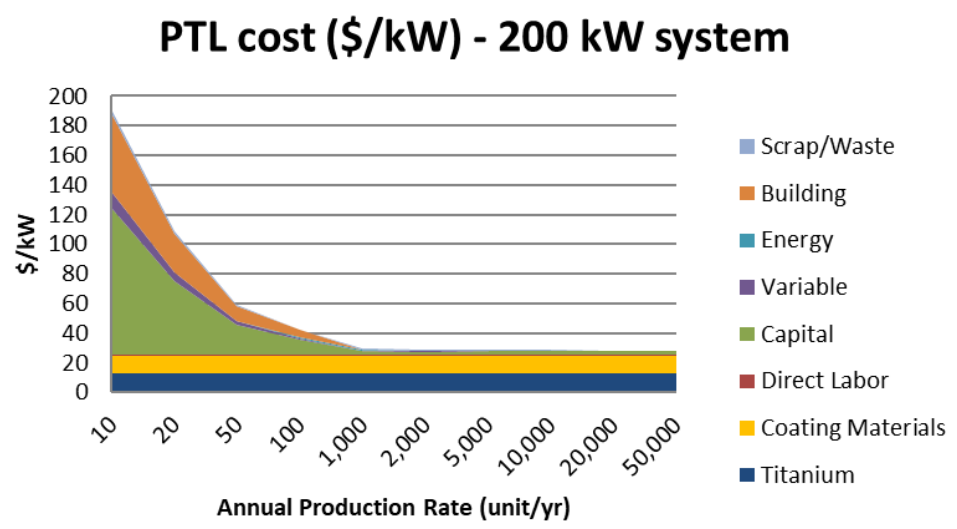

(c)
Building

Energy

- Variable

- Capital

- Direct Labor

- Coating Materials

- Titanium
- Scrap/Waste 


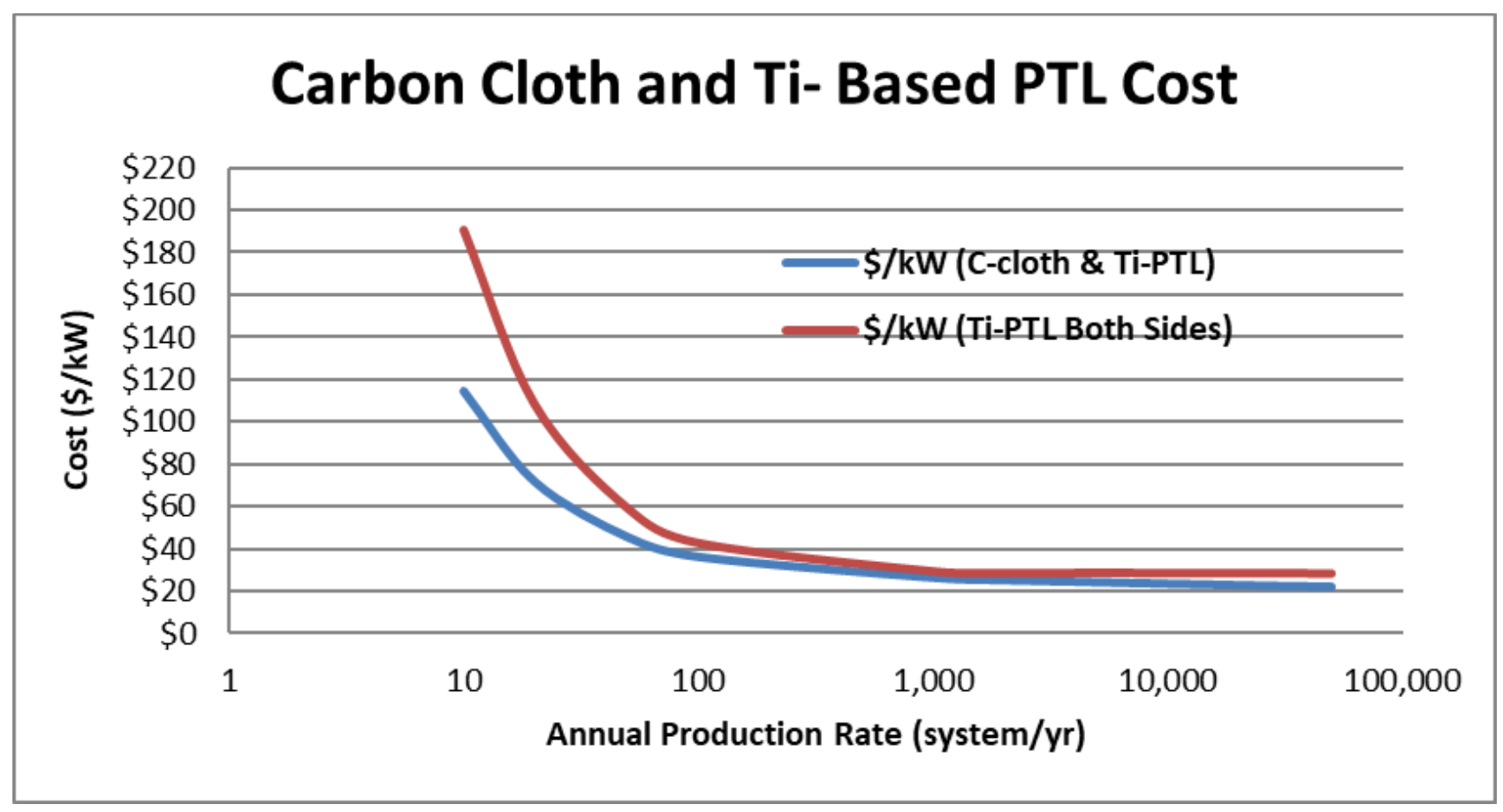

Figure 9. Cost of carbon cloth vs. Ti-based PTL 
Frame Cost (\$/pcs) -200 kW

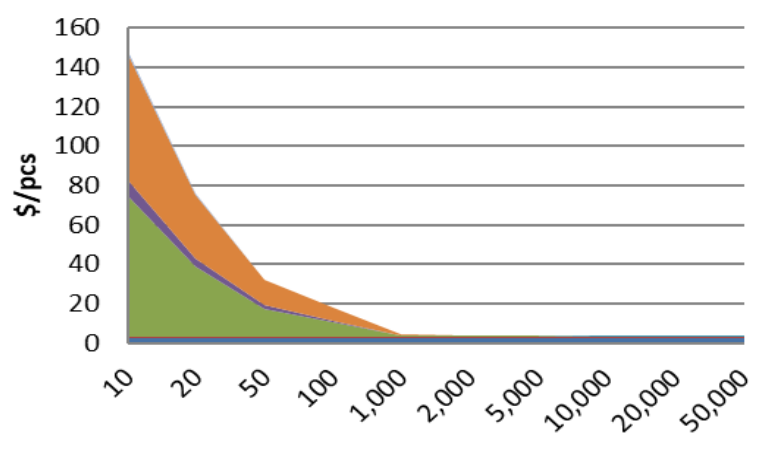

Annual Production Rate (unit/yr)

(a)

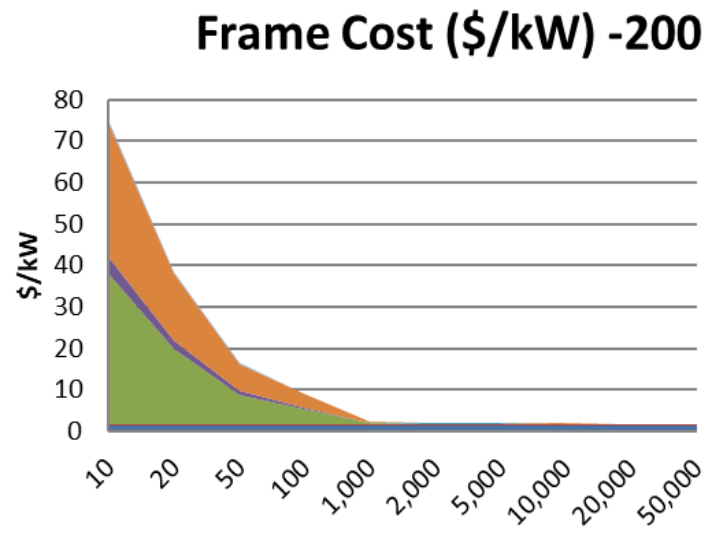

Annual Production Rate (unit/yr)

(c)

\section{- Scrap/Waste \\ Building \\ Energy \\ - Variable \\ - Capital \\ Direct Labor \\ - Direct Materials}

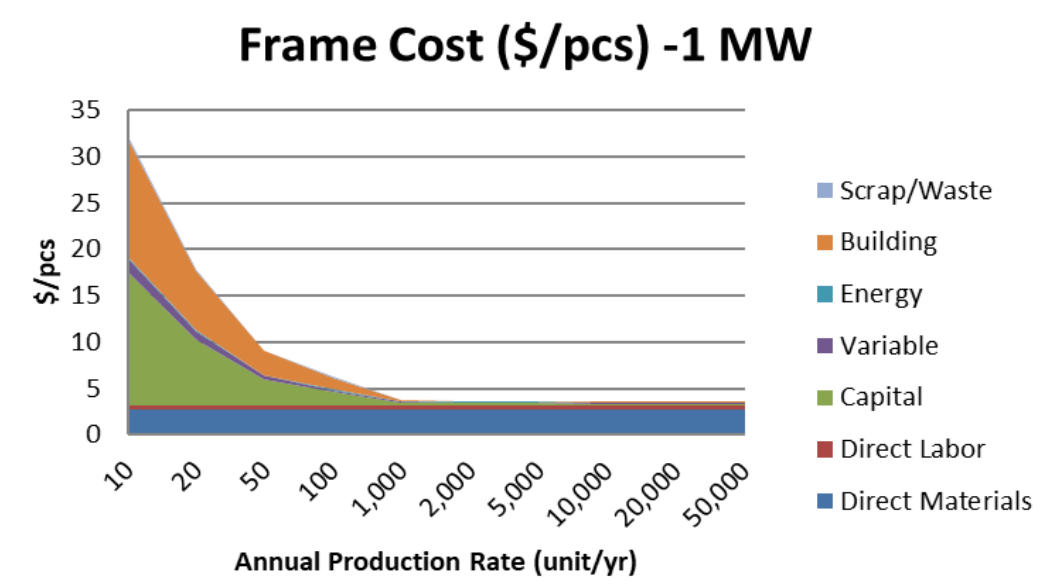

(b)



(d)

Figure 10. Manufacturing cost curves for the frame in (a) $\$ /$ piece for 200-kW system, (b) $\$ / k W$ for 200-kW system,

(c) \$/piece for 1-MW system, and (d) \$/kW for 1-MW system

The annual production rate is the number of electrolyzer systems produced in one year. 


\section{Bipolar Plate Cost (\$/pcs) - 200 kW system}

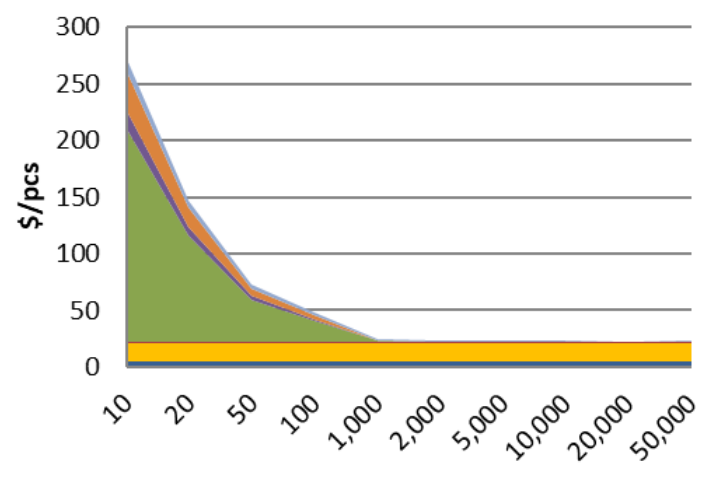

Annual Production Rate (unit/yr)

(a)

\section{Bipolar Plate Cost (\$/kW) - 200 kW system}

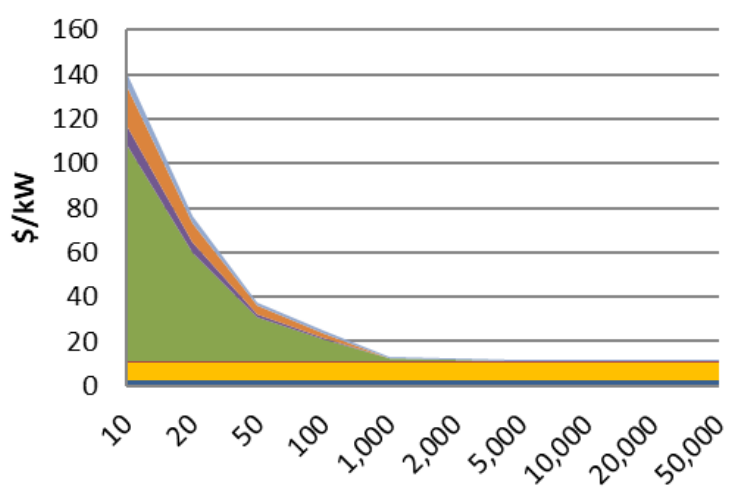

Annual Production Rate (unit/yr)

(c)
- Scrap/Waste

Building

- Energy

- Variable

- Capital

- Direct Labor

- Coating Materials

- Stainless Steel
Scrap/Waste

Building

- Energy

- Variable

- Capital

- Direct Labor

$\square$ Coating Materials

- Stainless Steel



Annual Production Rate (unit/yr)
- Scrap/Waste

Building

Energy

- Variable

- Capital

- Direct Labor

- Coating Materials

- Stainless Steel

(b)

\section{Biploar Plate Cost (\$/kW) - 1 MW system}

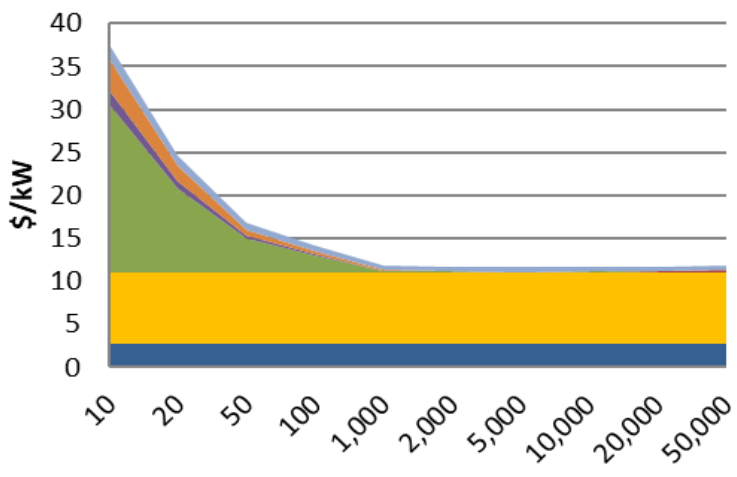

Annual Production Rate (unit/yr)

\section{- Scrap/Waste}

Building

- Energy

- Variable

- Capital

- Direct Labor

- Coating Materials

n Stainless Steel

(d)

Figure 11. Manufacturing cost curves for the stamped stainless-steel plates bipolar plates in (a) $\$ /$ piece for 200-kW system, (b) $\$ / k W$ for 200-kW system, (c) \$/piece for 1-MW system, and (d) \$/kW for 1-MW system

The annual production rate is the number of electrolyzer systems produced in one year. 
Stack Assembly Cost (\$/kW)- 200 kW

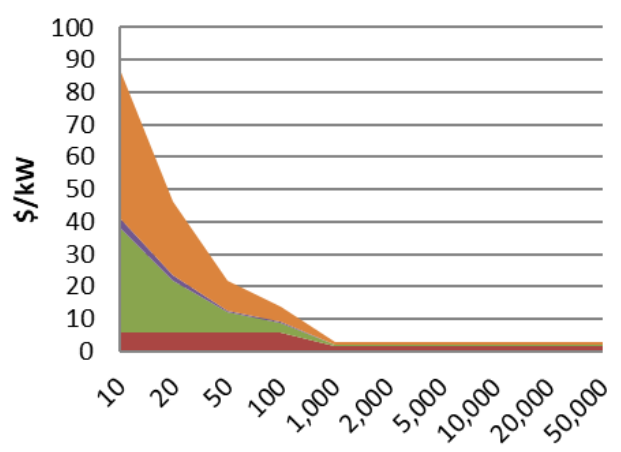

Annual Production Rate (unit/yr)

(a)

\section{Stack Assembly Cost (\$/kW)- 200 kW}

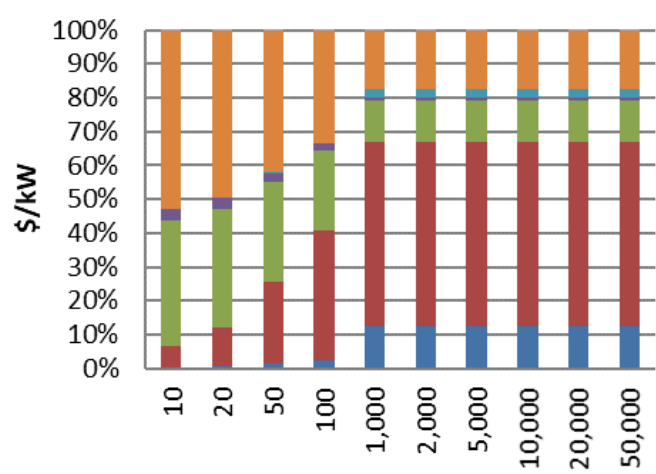

Annual Production Rate (unit/yr)

(c)
- Scrap/Waste $(\$ / \mathrm{kW})$ n Building $(\$ / \mathrm{kW})$ - Energy $(\$ / k W)$ - Variable $(\$ / \mathrm{kW})$ n Capital (\$/kW) - Direct Labor $(\$ / k W)$ - Direct Materials (\$/kW)

\section{- Scrap/Waste (\$/kW)} - Building $(\$ / \mathrm{kW})$ Energy $(\$ / k W)$ - Variable $(\$ / \mathrm{kW})$ - Capital $(\$ / \mathrm{kW})$ - Direct Labor (\$/kW) n Direct Materials $(\$ / \mathrm{kW})$

Figure 12. Manufacturing cost analysis for stack assembly process: (a) cost curve as a function of the annual production rate for 200kW system, (b) cost breakdown as a function of the annual production rate for 200-kW system, (c) cost curve as a function of the annual production rate for 1-MW system, and (d) cost breakdown as a function of the annual production rate for 1-MW system

The annual production rate is the number of electrolyzer systems produced in one year. 


\subsection{Balance-of-Plant Cost}

As discussed in Section 2, the "balance of plant" (BOP) consists of several subsystems that complement the function of the stack. Table 5 summarizes our cost estimates for the key parts in the BOP for a 1-MW system. To determine the cost of each component in the BOP, we collected cost data from direct quotes we received from parts vendors and from discussions with industry advisors to estimate the cost of the general-purpose parts such as stainless-steel pipes, pressure gauges, and water pumps.

The system discussed here reflects our best assessment of the existing or similar systems, but it does not necessarily capture all system components with exact fidelity to existing commercial systems. Moreover, existing physical or commercial systems may not have the exact design or parts we describe here. Thus, this analysis should be used as an informative tool, and it should not be considered an analysis of any commercial products.

Because many generic parts are used in the BOP, there is a potential room for savings by purchasing larger quantities. In this analysis, we applied the discount values as a function of purchase quantity, using the quotes we received directly from sales representatives. We also assumed a $20 \%$ price scaling for a $10 \mathrm{x}$-factor increase in the purchased quantity for the generic and power electronics parts that did not come with direct quotes from the part vendors (Wei et al., 2014; Saggiorato et al. 2017; Contini et al., 2017). The rationale behind this assumption is that other clean energy technologies (e.g., photovoltaic solar cells and li-ion batteries) have experienced significant cost reductions in the past decade or so (more than $20 \%$ reduction in the price for doubling of the cumulative shipped volume (Liebreich, 2014). We think that fuel cells and electrolyzers could follow such trend in the coming years when the production volumes become at scale. Other factors that could also play role in reducing the cost of these parts are improvements in the part performance, thus less material or smaller parts could be manufactured in the future and improvements in the manufacturing processes of these parts. Schmidt et al., (2017b) estimated the learning experience rate for fuel cells and electrolyzers to be around 18\% compared to $12 \%$ for li-ion batteries used in residential and utility applications. This means we could see larger cost reductions in the fuel cells and electrolyzers prices with production volumes.

The cost breakdown of the BOP in Figure 13a and 13b shows that about $29 \%$ of the BOP part cost for the 200-kW and half the cost in the 1-MW system come from the power supplies, which includes an expensive $\mathrm{AC} / \mathrm{DC}$ rectifier that is designed to supply certain current to the cells in the stack. Cost breakdown in Figures 13a and 13b is based on purchasing 1 unit. Cost curve for other annual production rates (a proxy of the purchased quantities) is shown in Figures 13c and $13 \mathrm{~d}$ for $200 \mathrm{~kW}$ and $1 \mathrm{MW}$ systems, respectively. For the 1-MW system, a deionized water circulation system and a hydrogen processing unit contribute to about one-fifth each. Cooling system shares about $11 \%$ and $7 \%$ of the total BOP part cost for the $200-\mathrm{kW}$ and $1-\mathrm{MW}$ systems respectively.

The cost of the oxygen tank is relatively high because we assume it is made from 316 stainless steel, electropolished, passivated, pickled, oxygen-cleaned tank; rated at $150 \mathrm{psi}$ working pressure (ASME-stamped). However, other cheaper alternatives can also be used in the BOP, for example we can use a smaller size atmospheric vessel that does not capture oxygen which could cost one-third to one-fourth the cost of the stainless-steel tank. A polypropylene-based tank could 
also be used for just a few thousand dollars. Overall, using cheaper tanks could save a couple dollars per $\mathrm{kW}$ in the system cost, but that means that pure oxygen is vented to the atmosphere and we lose a high value by-product which can be sold for other end-uses. 


\section{BOP Cost Breakdown- 200kW System}

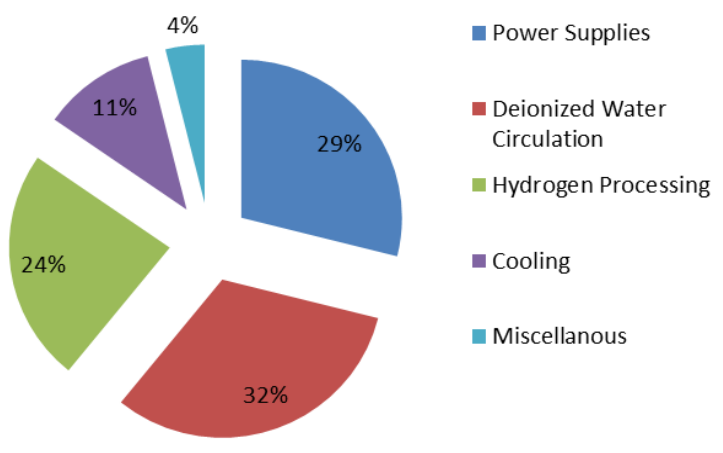

(a)



(c)

\section{BOP Cost Breakdown- 1MW System}


- Power Supplies

n Deionized Water Circulation

- Hydrogen Processing

- Cooling

Miscellanous

(b)

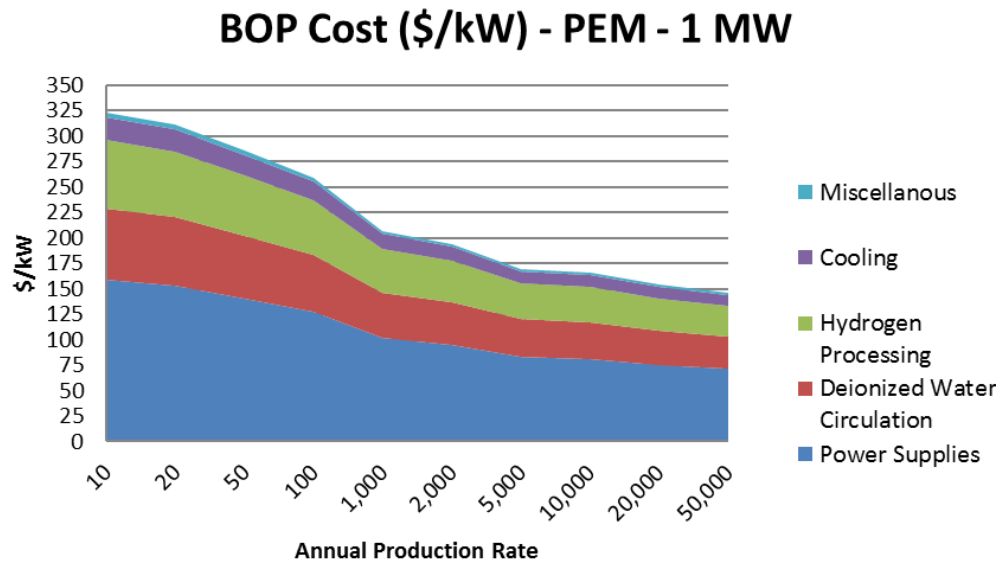

(d)

Figure 13. Cost breakdown for the BOP parts for (a) 200-kW system (cost for 1 item) and (b) 1-MW system (cost for 1 item), (c) cost breakdown as a function of the annual production rate for $200-\mathrm{kW}$ system, and (d) cost curve as a function of the annual production rate for 1-MW system 
Table 5. Cost of the Balance-of-Plant Parts (cost of one item)

\begin{tabular}{|c|c|c|c|}
\hline System & Subsystem & 200 kW & $1 \mathrm{MW}$ \\
\hline \multirow[t]{4}{*}{ Power Supplies } & Power Supply & $\$ 44,000$ & $\$ 198,000$ \\
\hline & DC Voltage Transducer & $\$ 225$ & $\$ 225$ \\
\hline & DC Current Transducer & $\$ 340$ & $\$ 340$ \\
\hline & Total & $\$ 44,565$ & $\$ 198,225$ \\
\hline \multirow{7}{*}{$\begin{array}{l}\text { Deionized Water } \\
\text { Circulation }\end{array}$} & Oxygen Separator Tank ${ }^{\dagger}$ & $\$ 20,000$ & $\$ 40,000$ \\
\hline & Circulation Pump & $\$ 7,053$ & $\$ 10,962$ \\
\hline & Polishing Pump & $\$ 2,289$ & $\$ 5,000$ \\
\hline & Piping & $\$ 10,000$ & $\$ 15,157$ \\
\hline & $\begin{array}{l}\text { Valves and Instrumentation } \\
\text { - Pressure, temperature, conductivity, flowmeter } \\
\text { - A Class I, Division 2, Group B rating drives up prices. }\end{array}$ & $\$ 7,500$ & $\$ 11,368$ \\
\hline & Controls & $\$ 2,000$ & $\$ 4,595$ \\
\hline & Total & $\$ 48,842$ & $\$ 87,082$ \\
\hline \multirow[t]{6}{*}{ Hydrogen Processing } & Dryer Bed & $\$ 13,860$ & $\$ 36,589$ \\
\hline & Water/Hydrogen Separator & $\$ 10,000$ & $\$ 26,390$ \\
\hline & Tubing & $\$ 5,000$ & $\$ 7,579$ \\
\hline & $\begin{array}{l}\text { Valves \& Instrumentation } \\
\text { - Pressure, temperature, conductivity, flowmeter }\end{array}$ & $\$ 5,000$ & $\$ 7,579$ \\
\hline & Controls & $\$ 2,500$ & $\$ 5,743$ \\
\hline & Total & $\$ 36,360$ & $\$ 83,880$ \\
\hline \multirow[t]{3}{*}{ Cooling } & Plate heat exchanger & $\$ 9,000$ & $\$ 10,525$ \\
\hline & Cooling pump & $\$ 1,500$ & $\$ 3,797$ \\
\hline & Valves, instrumentation & $\$ 2,000$ & $\$ 4,595$ \\
\hline
\end{tabular}






$\dagger$ This cost is for 316SS, electropolished, passivated, pickled, oxygen-cleaned tank; 150 psi working pressure rating, ASME-stamped. It has multiple large nozzles integrated into the design for versatility and expansion, plus vortex breaker, and has large manway access for oxygen-cleaning operation.

\subsection{PEM Electrolyzer System Cost}

Stack and system costs are shown in Figures 14 and 15, respectively. The stack cost curves in Figures 14a and 14b show the effect of the annual production rates on the total stack cost for 200-kW and 1-MW stacks respectively. As with the trends we saw in the cost analysis for stack parts, we expect stack cost to decrease with higher annual production rates. Figure $14 \mathrm{c}$ and $14 \mathrm{~d}$ show that stack cost is dominated by the CCM cost, followed by the following parts in order from high-cost to low-cost contributions: PTL, assembly and end-plates, bipolar plates and frame/seal. The CCM consists of a Nafion membrane and platinum group metals, where Nafion membrane shares about one-third to half of the CCM cost and 13-46\% for PGM catalyst.

There is no clear cutoff identifying the point where economies of scale are met on the stack cost, but based on current market demands and our experience, that producing 1,000 electrolyzer stacks per year is within the range that is considered "economies of scale." 
Stack Cost $(\$ / k W)-200$ kW

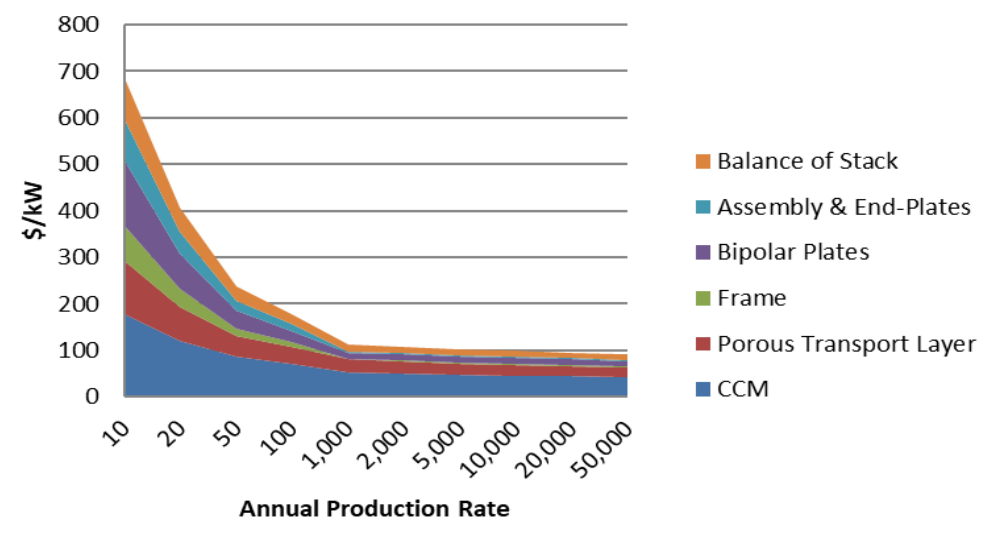

(a)

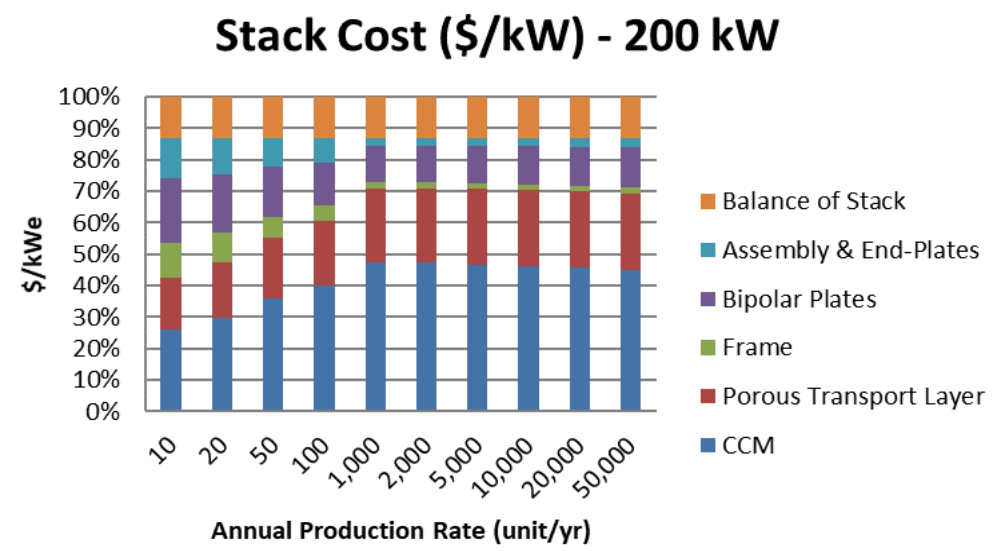

(c)

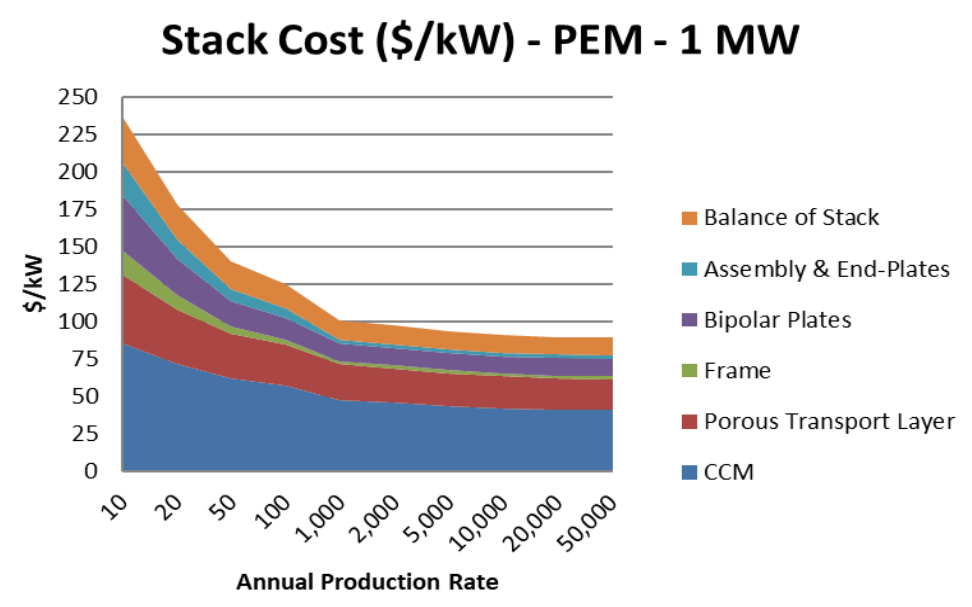

(b)

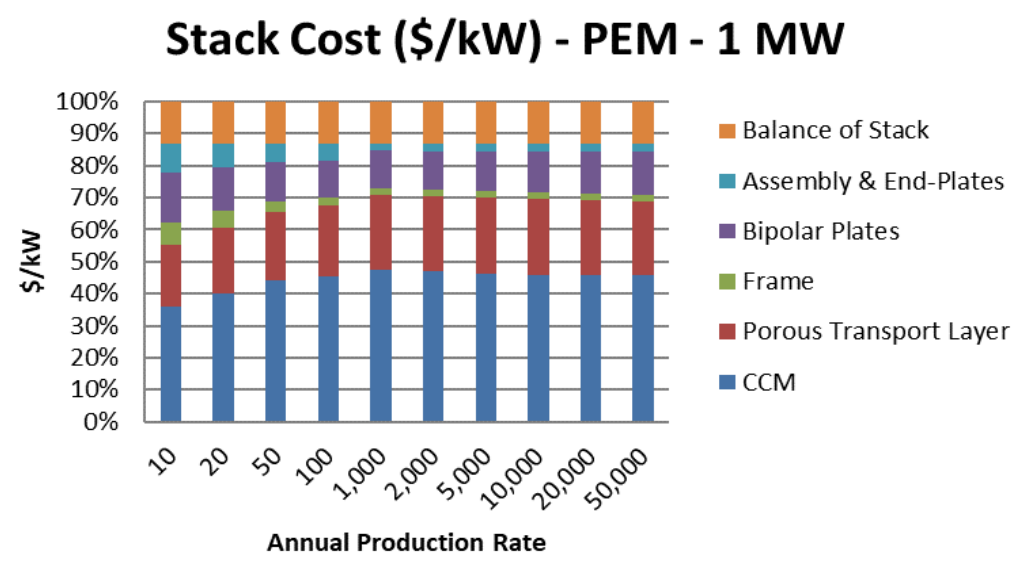

(d)

Figure 14. Manufacturing cost curve for (a) 200-kW PEM electrolyzer stack, (b) manufacturing cost curve for 1-MW PEM electrolyzer stack, (c) cost breakdown for 200-kW stack, and (d) cost breakdown for 1-MW stack

The annual production rate is the number of electrolyzer systems produced in one year. 
The system cost shown in Figure 15 is the summation of the stack and BOP costs. BOP costs for 200-kW and 1-MW systems dominate the total system cost across all annual production rates. Since BOP parts are outsourced from part vendors, we do not expect economies of scale to have the same effect on the system cost as in the case of stack that is manufactured in-house. Power electronics including power supplies (AC/DC rectifier), current and voltage transducers, dominate the BOP cost. Similar findings were also observed in the stationary fuel cell systems where power electronics share significant part of the BOP cost (see Wei et al., 2014, Collela et al., 2014; James et al., 2015). It seems that a follow-up work is needed to study the key cost drivers in the production of the power electronics for PEM electrolyzer system. The second cost contributor at the BOP is the deionized water circulation unit, which contains an expensive water/oxygen separation tank that separates oxygen and water coming out of the stack. 


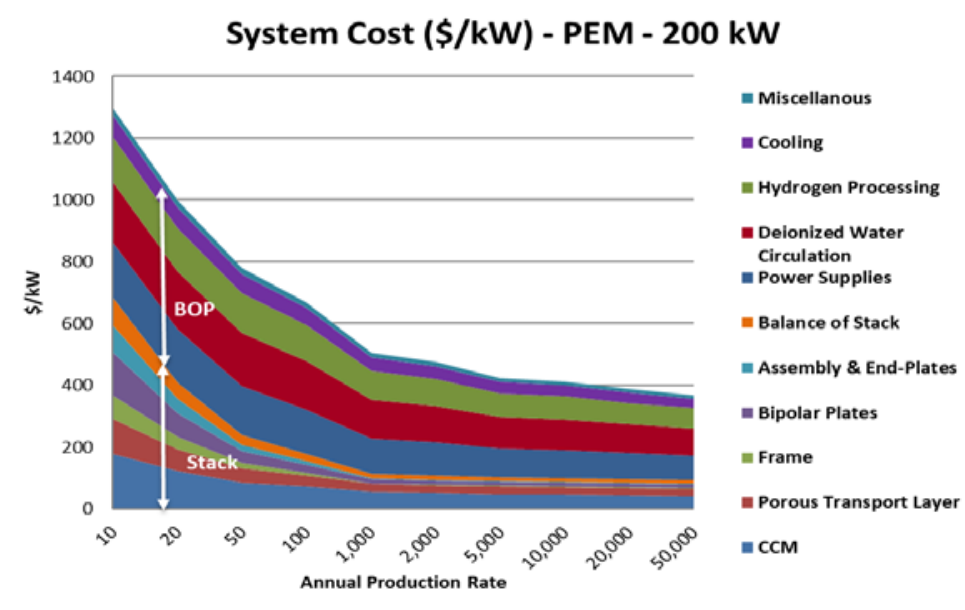

(a)



(c)

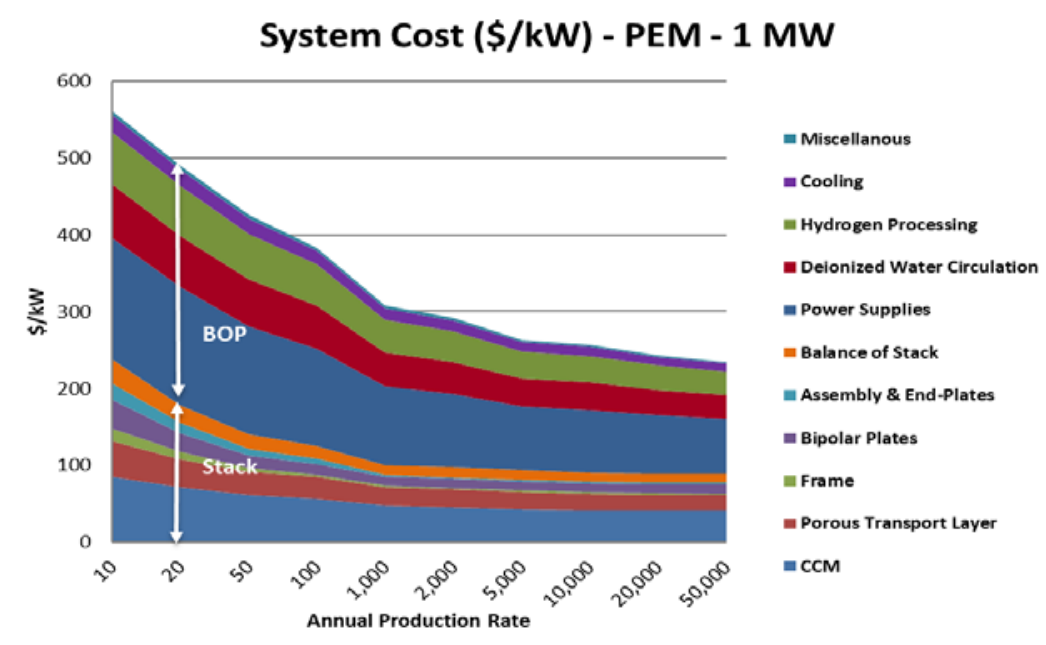

(b)

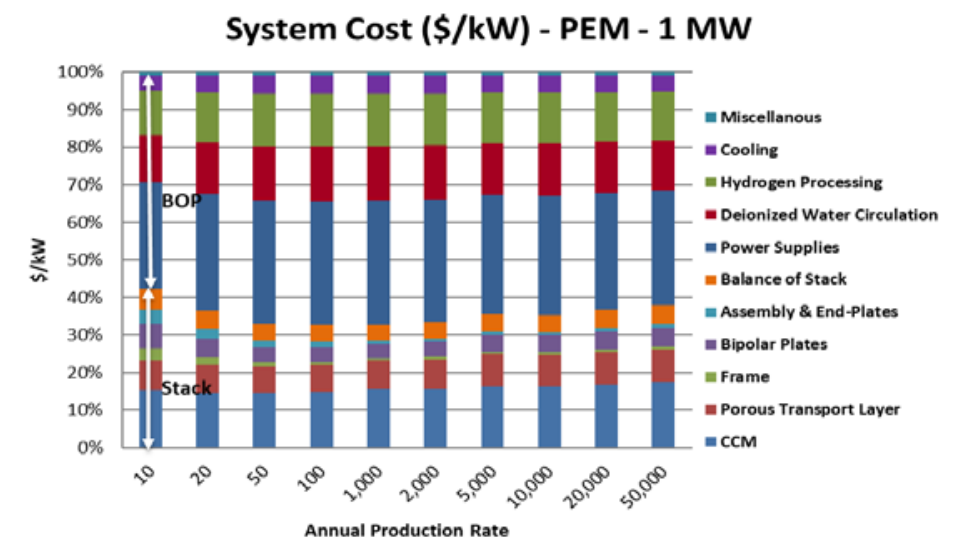

(d)

Figure 15. Cost curves for (a) 200-kW and (b) 1-MW electrolyzer systems showing costs of stack and BOP, and cost breakdown for (c) 200-kW and (d) 1-MW electrolyzer systems at different annual production rates

The annual production rate is the number of electrolyzer systems produced in one year. 


\section{Sensitivity Analysis and Potential Cost Reductions}

Sensitivity analysis allows us to study the impact on the overall stack and system costs of changing certain parameters in the manufacturing process or varying some parameters in the cell design. While we tried to use consistent values in this analysis $( \pm 20 \%$ of the base value for each parameter), we thought that some parameters may change beyond this range in the near term. For example, some manufacturers are working to reduce the platinum group metal loadings from 11 $\mathrm{g} / \mathrm{m} 2$ that are currently used in some commercial system to less than $1 \mathrm{~g} / \mathrm{m} 2$ in the near term (see for example Ayers 2015; Yu et al., 2015; Xu 2016). Nafion 117 membrane is expensive. Today, there are several cheaper alternatives used in PEM electrolysis environment such as SPEEK (sulfonated poly(ether ether keton)) and Solvay Aquivion PFSA (perfluorosulfonic acid) membranes (Hansen et al., 2012)

A sensitivity analysis at the stack level was made for $200-\mathrm{kW}$ and 1-MW systems at different production volumes (as shown in Figure 16). We can see that stack cost is more sensitive to manufacturing process yields (including process yeild for CCM coating, PTL powder metallurgy, plate stamping and coating, and stack assembly) and power density. Pt loading and Nafion membrane cost are among some of the important factors that have large impacts on the stack cost. This is unsurprising for high-cost materials, especially when material cost starts to dominate at high production volumes. The cost of commodities such as titanium, stainless steel and PPS-40\%GF is not a large factor in relative to the manufacturing yield, power density, and platinum loading.

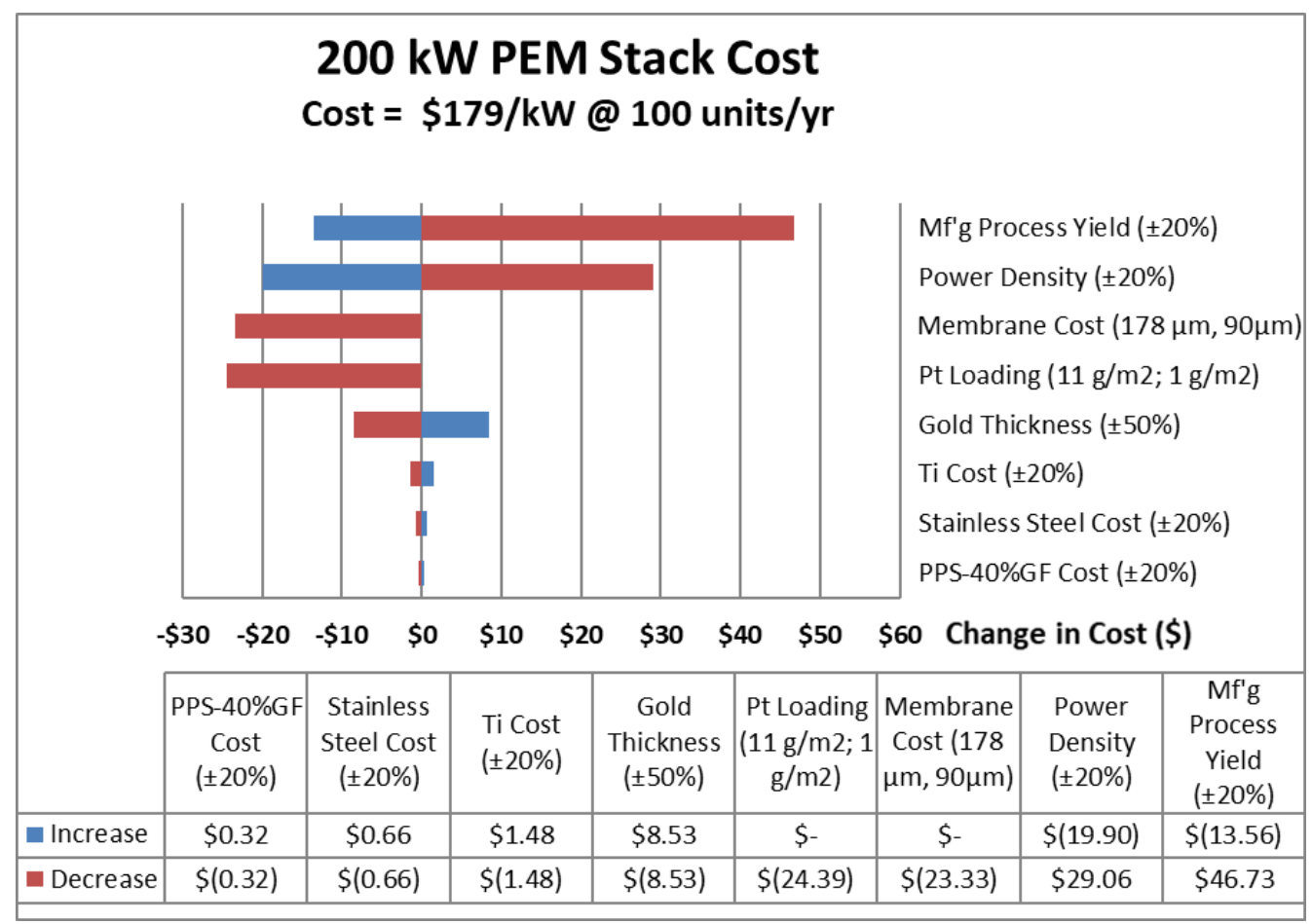

(a) 




(b)

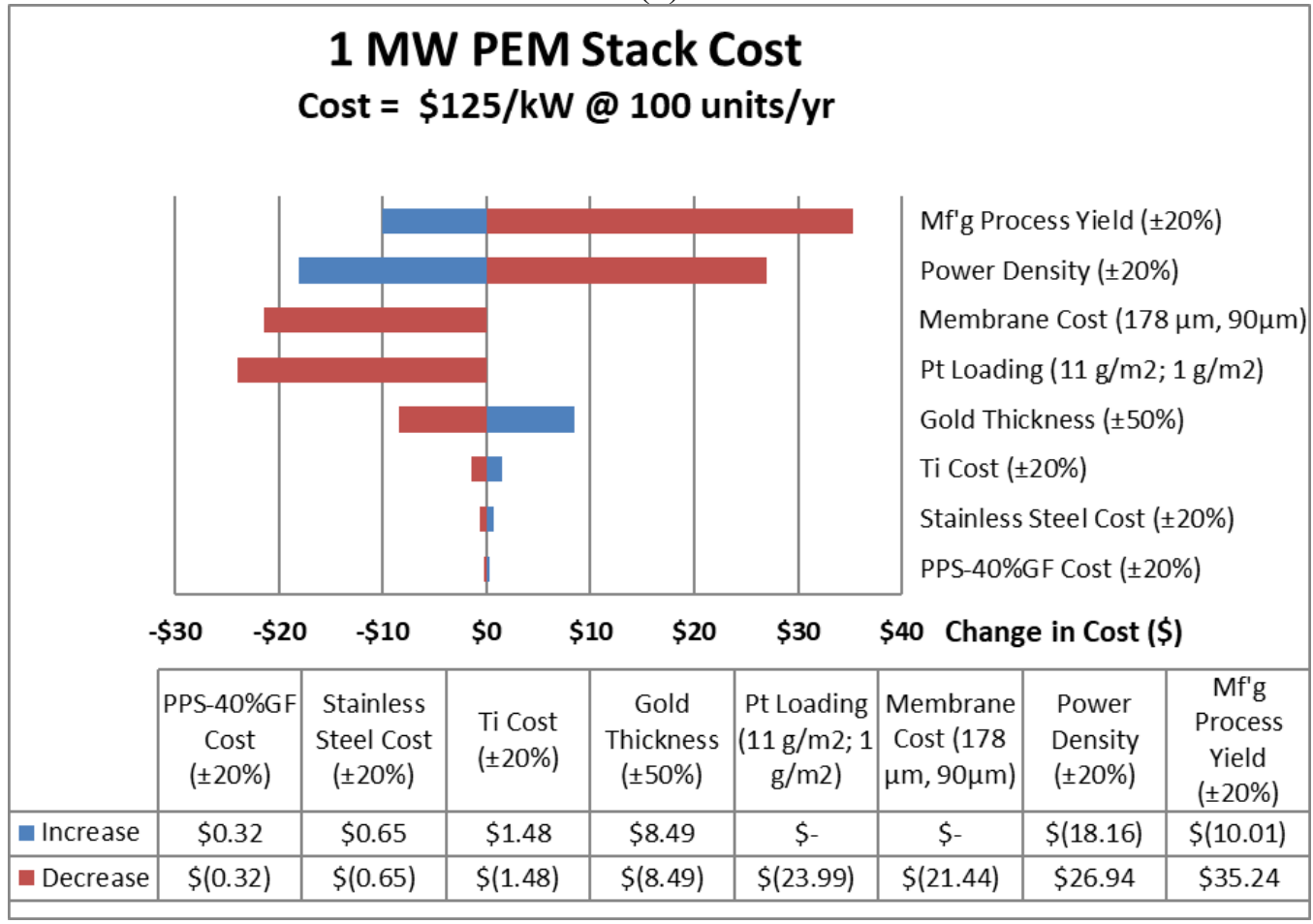

(c) 


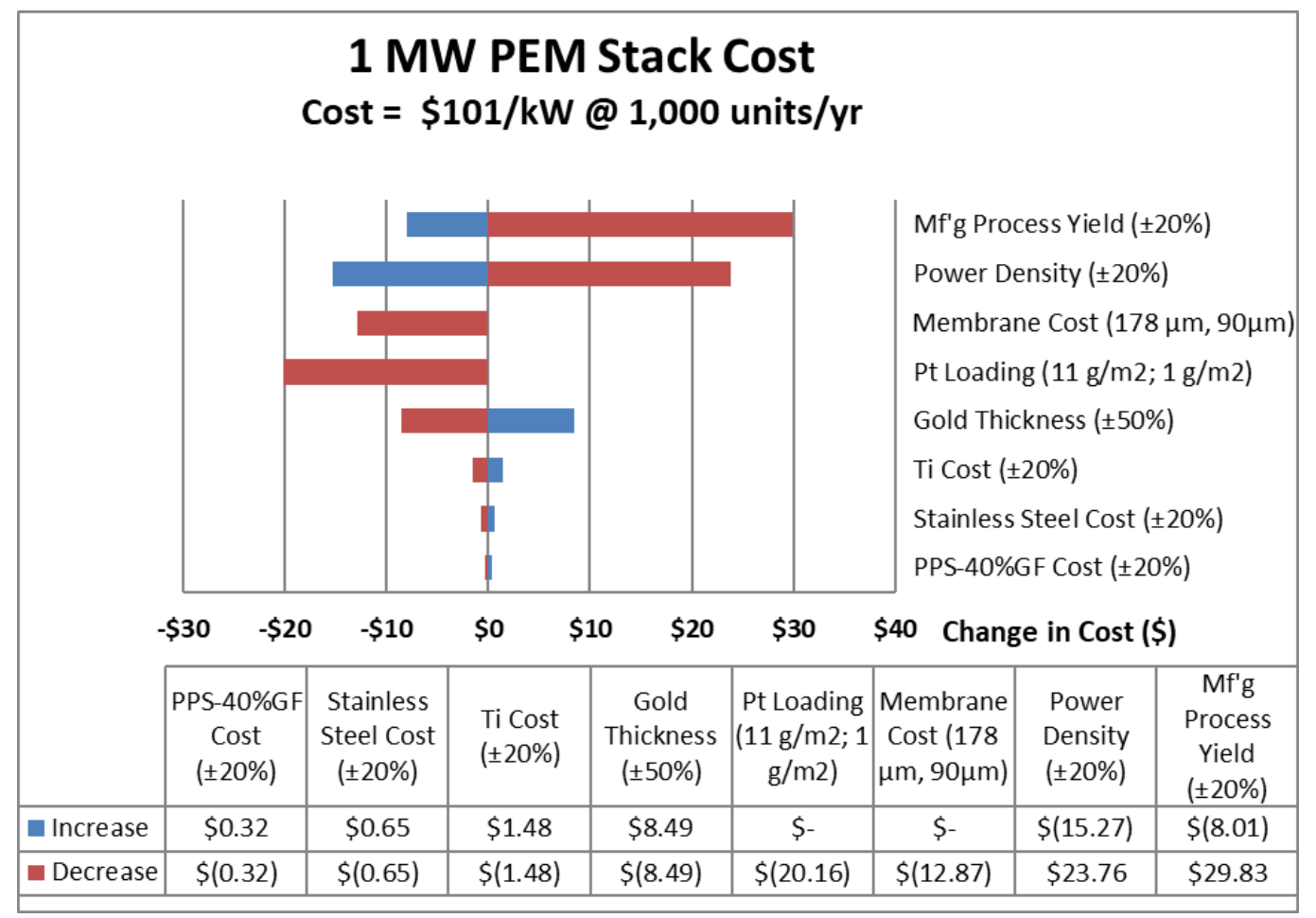

(d)

Figure 16. Impact of changing some manufacturing and cell design parameters on 200-kW PEM stack cost: (a) at 100 units/yr, and (b) at 1,000 units/yr, and 1-MW stack cost at (c) at 100 units/yr, and (d) at 1,000 units/yr

The annual production rate is the number of electrolyzer systems produced in one year.

Pt loading was varied between $11 \mathrm{~g} / \mathrm{m}^{2}$ (nominal value) and $1 \mathrm{~g} / \mathrm{m}^{2}$, Membrane cost for Nafion 117 (thickness $=178 \mu \mathrm{m}$ ) from DuPont (base case) and Aquivion ES98-09S (thickness $=90 \mu \mathrm{m}$ ) from Solvay

We also investigated the potential areas where we could potentially target a cost reduction, including cost reductions from changing certain design parameters or the costs of certain key materials used in the PEM stack. We found that manufacturing engineering and economies of scale play a key role in reducing the cost of the PEM system (Figure 17). Some design changes in the MEA cells, such as reductions in platinum group metal loading and any possible cost reduction in the membrane cost, could also play role in decreasing the cost of the electrolyzer system. A $20 \%$ improvement in the power density and using cheaper membrane could reduce the cost of the stack significantly. Cost of the power electronics remains the largest portion of the cost in the PEM electrolyzer system. So, we expect that any reduction in the power electronics cost to have a great impact in the PEM electrolyzer cost, as shown in Figure 17.

The combination of the abovementioned scenarios could reduce the cost of the PEM electrolyzer stack from $\$ 237 / \mathrm{kW}( \pm 10 \%)$ at a production volume of $10 \mathrm{MW}$ (e.g., 1-MW systems at a production rate of 10 units/year) to $\$ 69 / \mathrm{kW}$ at 1,000 MW (e.g., 1-MW systems at 1,000 unit/year). System cost, including stack and balance of plant, could also be reduced through manufacturing economies of scale, improvements in power density, reduction in platinum group 
metal loading and membrane cost, and reductions in power electronics - from $\$ 561 / \mathrm{kW}( \pm 10 \%)$ for the 1-MW electrolysis system at 10 units/year to $\$ 265 / \mathrm{kW}( \pm 10 \%)$ at 1,000 units/year.

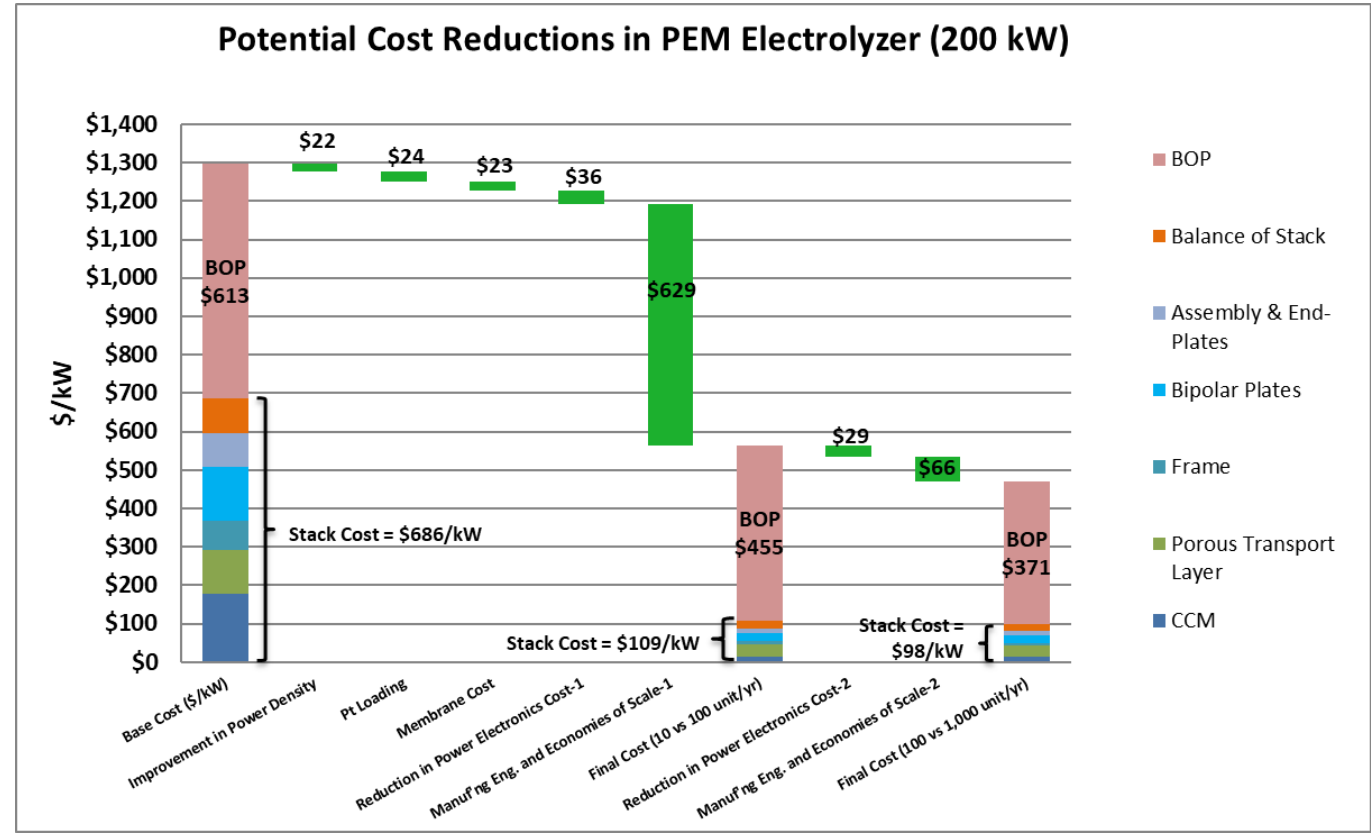

(a)

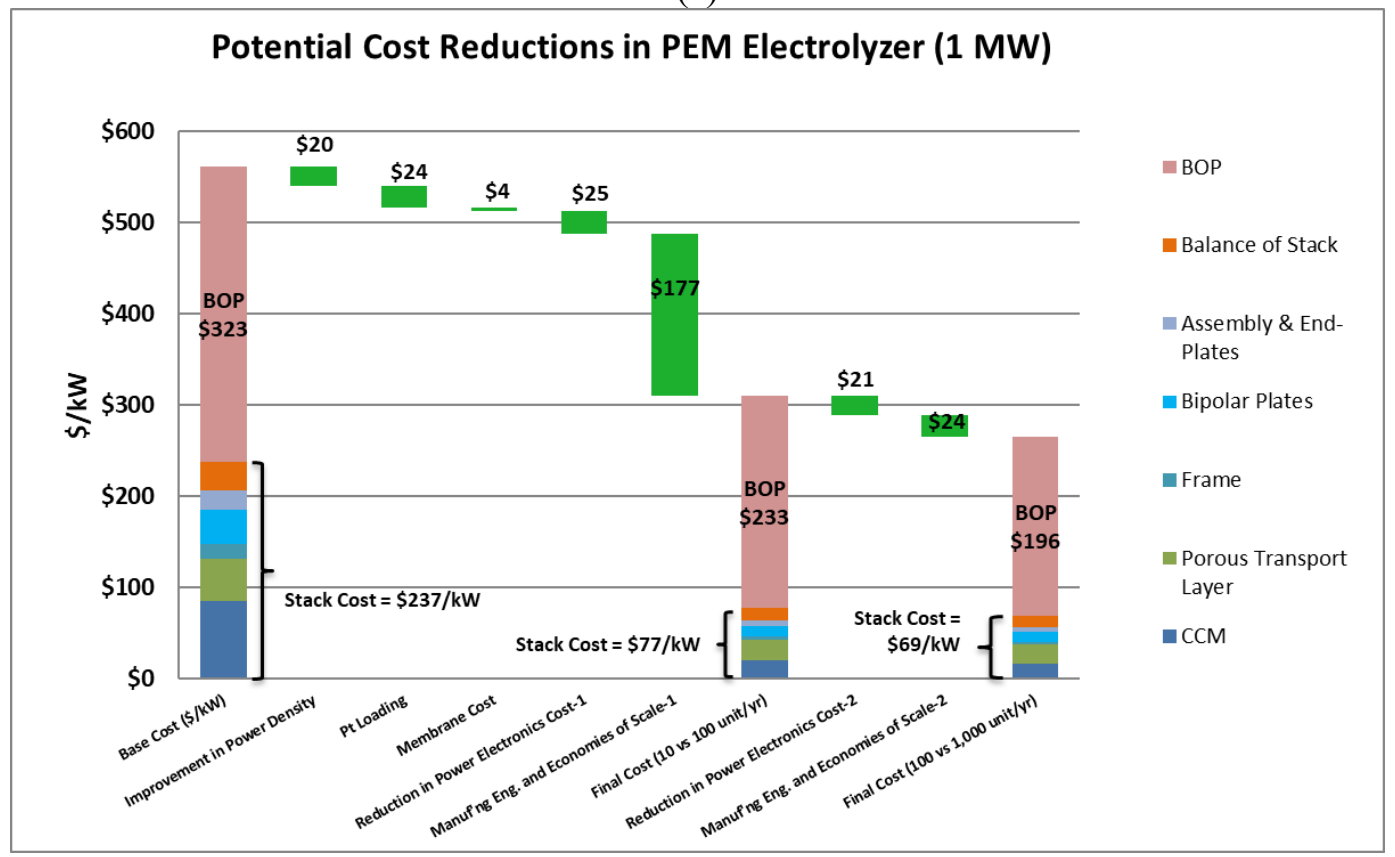

(b)

Figure 17. Waterfall charts showing areas where R\&D can play a role in reducing the cost of the electrolysis system for (a) $200 \mathrm{~kW}$ system and (b) 1-MW system

Assumptions: improvement in power density (+20\%); Pt loading from $11 \mathrm{~g} / \mathrm{m}^{2}$ to $1 \mathrm{~g} / \mathrm{m}^{2}$, membrane cost (Nafion 117 vs. Solvay E98-09S), and power electronics (-20\%). Economy of scale is the manufacturing cost of 10 units/yr vs. 100 units/yr vs. 1,000 units/yr. 


\section{Installed System Cost}

Installed system cost was estimated using the following assumptions:

- A markup factor (50\% of the total system cost) accounts for profit margin, general and administration, sales and marketing, warranty costs, and other such costs. This estimate for the "factory gate price" is consistent with the previous technoeconomic studies for fuel cells (see James and DeSantis 2015; Saggiorato et al. 2017; Wei et al. 2014)

- Another $33 \%$ was added to the factory gate price to estimate the installation cost (Wei et al. 2014)

Figure 18 shows the installed system cost for 200-kW and 1-MW PEM electrolyzer systems. Both markup and installation costs depend on the estimated system cost and follow the same trend of the system cost. That means we expect markup and installation cost to decrease with annual production rates and the expected impact of economies of scale in all cost components, including the markup factor. Additional cost reductions may be possible due to learning and cumulative experience that are developed by system providers and installer with time (Mayyas and Mann 2018).



(a) 




(b)

Figure 18. Installed system cost for (a) 200-kW PEM electrolyzer system, and (b) 1-MW PEM electrolyzer system

Other technoeconomic studies reported similar cost ranges. For example, Strategic Analysis Inc. estimated the uninstalled PEM electrolysis system cost to be around $\$ 940 / \mathrm{kW}$ (in 2012 dollars) (Colella et al., 2014). Their estimate for future forecourt that can produce up to $1,500 \mathrm{~kg}-\mathrm{H}_{2}$ per day is $\$ 450 / \mathrm{kW}$. In this report, authors also the potential cost reduction of huge central PEM plant that can produce up to $50,000 \mathrm{~kg}-\mathrm{H}_{2}$ per day. Their estimate for capital cost of the future central PEM plant could reach as low as $\$ 400 / \mathrm{kW}$. Thomas (2018), as part of the cost analysis done for Hydrogenics, estimated the price of a MW-scale PEM electrolysis system to be around $\$ 1,000 / \mathrm{kW}$ by 2030 , and $\$ 550 / \mathrm{kW}$ by 2050 . This price, however, can be reduced to $\$ 700 / \mathrm{kW}$ and $\$ 385 / \mathrm{kW}$ for multi-MW system in 2030 and 2050, respectively. 


\section{Effect of Electrolyzer Capital Cost on the Hydrogen Production Cost}

We used the $\mathrm{H} 2 \mathrm{~A}^{4}$ model to study the effect of decreasing the capital cost of the electrolyzer on the hydrogen production cost. Figure 19 shows several scenarios of capital cost for $1 \mathrm{MW}$ electrolysis system using two annual production rates: 10 units/yr and 1,000 units per year. These production rates, in our opinion, could represent the current production volumes and future production rates at economies of scale. We also tried to combine this effect with another important parameter, electricity price. If we look at the capital cost contribution for $97 \%$ capacity factor (i.e., the percentage of time we use the electrolyzer to generate hydrogen), we can see that the cost of hydrogen can be lowered by (1) reducing the capital cost of the electrolyzer and (2) using less-expensive electricity in the electrolysis process. However, if the capacity factor of the electrolyzer is decreased to lower values, we expect the capital cost contribution to increase because of spreading the capital cost over a shorter period of operation periods and smaller amounts of the generated hydrogen.

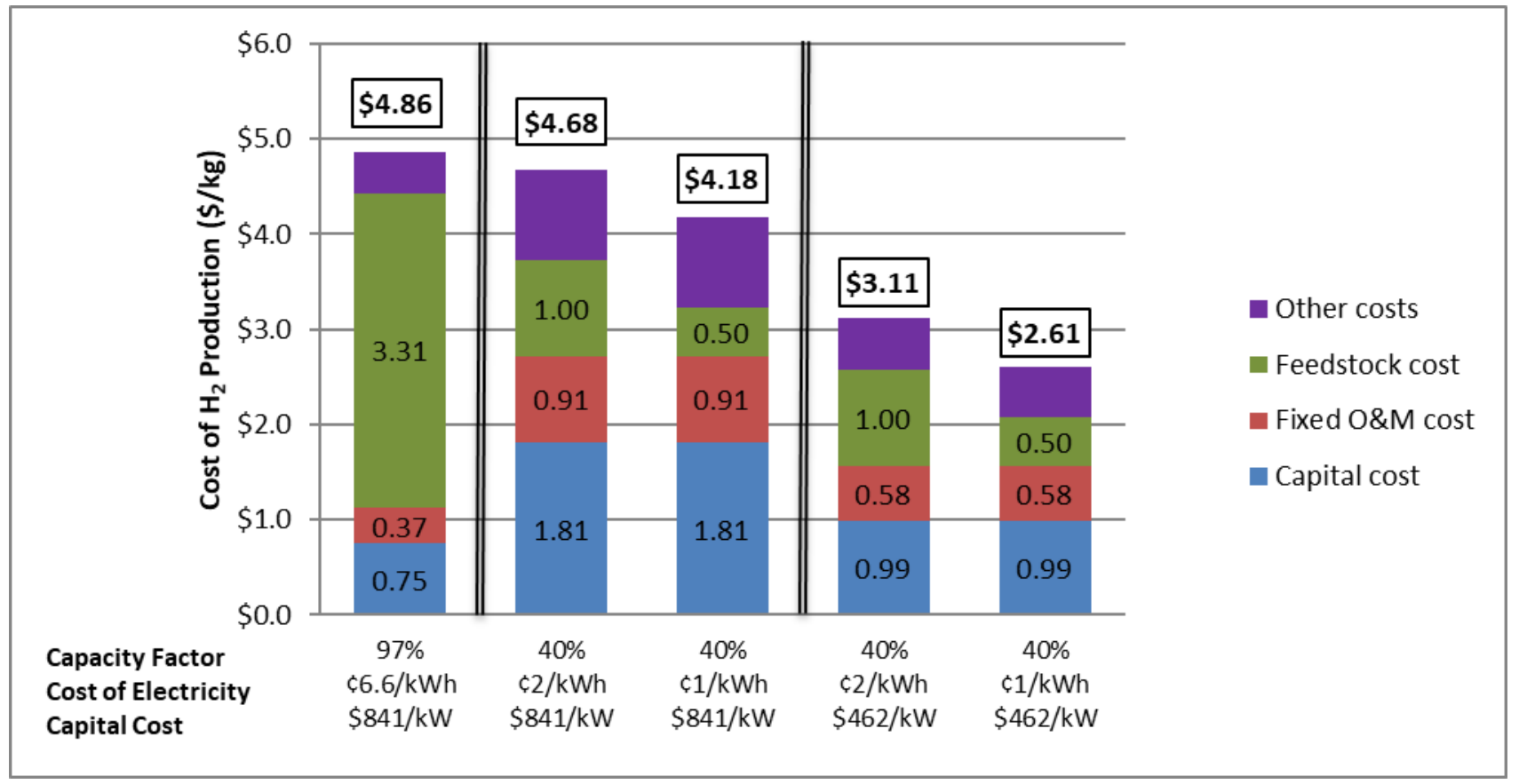

Figure 19. Effect of the capital cost, capacity factor, and electricity price on the cost of hydrogen production (excluding compression, storage and dispensing CSD cost)

Assumptions: (1) 1-MW PEM electrolyzer, (2) system cost includes markup factor (50\%), and (3) economies of scale: cost of producing 10 units/yr (cost is $\$ 841 / \mathrm{kW}$ ) versus 1,000 units $/ \mathrm{yr}$ (cost is $\$ 462 / \mathrm{kW}$ )

\footnotetext{
${ }^{4}$ For information about H2A model, see "DOE H2A Analysis," https://www.hydrogen.energy.gov/h2a analysis.html.
} 


\section{Conclusions}

The development of high throughput, automated processes achieving high yield are estimated to push the cost per kilowatt for the PEM electrolyzer stack to $\$ 125 / \mathrm{kW}( \pm 10 \%)$ for an overall production volume of $100 \mathrm{MW}$ (e.g., 1-MW systems x 100 units/year). The stack cost could be pushed as low as $\$ 90 / \mathrm{kW}( \pm 10 \%)$ at 50,000 systems/year. At low volumes the stack cost is sharply reduced when moving from a production volume of 10 to 1,000 systems per year, because tool utilization increases rapidly, and capital and facility costs drop sharply.

Direct material costs dominate stack costs at high volume. For the PEM electrolyzer stacks, depending on the annual production rate, we found that CCM manufacturing cost is about 26\%$47 \%$ for $200-\mathrm{kW}$ PEM stack and about $36 \%-47 \%$ for the $1-\mathrm{MW}$ stack, with PTL contributing around $17 \%-25 \%$ of the stack cost, bipolar plates about $12 \%-21 \%$, and end plates and assembly near 3\%-13\%. In terms of cost-dominating factors at the stack level, it was found that manufacturing process yield, power density, gold layer thickness on PTL and bipolar plates and Pt loading and/or Pt price contribute most to the overall stack cost.

Balance-of-plant costs for a 1-MW electrolyzer contribute to about two-thirds of the system cost, with power electronics contributing half the BOP cost, while the water circulation and hydrogen processing subsystems each share about one-fifth of the BOP cost. System cost including stack and BOP could also be pushed down with economies of scale. The uninstalled $1 \mathrm{MW}$ system cost could be reduced from $\$ 560 / \mathrm{kW}$ at 10 units/year to $\$ 258 / \mathrm{kW}$ at 10,000 units/year.

Electricity price and electrolyzer capital cost are the most important factors that determine the cost of hydrogen production in the water electrolysis process, so any cost reduction in the electrolyzer cost would reflect in lowering the cost of hydrogen generation process. 


\section{References}

AFDC (Alternative Fuels Data Center). n.d. "Hydrogen Production and Distribution."

U.S. Department of Energy. https://www.afdc.energy.gov/fuels/hydrogen_production.html

Air Products. 2013. Steam Methane Reformer: Overview. Air Products. (35981) 352-13-008-US. http://www.airproducts.com/ /media/Files/PDF/industries/energy/energy-hydrogen-steammethane-reformer-datasheet.pdf.

Anderson E., Ayers, K., Capuano, C., Szymanski, S. 2013. Long Life PEM Water Electrolysis Stack Experience and Future Directions. Technical Forum Hannover Messe, Germany. 9 April 2013

Ayers, K.E. Renner, J.N. Danilovic, N., Wang, J.X., Zhang, Y., Maric, R., Yu, H. 2016. Pathways to ultra-low platinum group metal catalyst loading in proton exchange membrane electrolyzers. Catalysis Today262(2016) 121-132

Ayers, K. 2015. Single Step Manufacturing of Low Catalyst Loading Electrolyzer MEAs. U.S. DOE Advanced Manufacturing Office Program Review Meeting Washington, D.C. May 28-29, 2015. https://www.energy.gov/sites/prod/files/2015/06/f23/P7AMO\%20Merit\%20Review\%202015\%20-\%20Proton\%20Final.pdf

Ayers, K.E., C. B. Capuano, and E. B. Anderson. 2012. "Recent Advances in Cell Cost and Efficiency for PEM-Based Water Electrolysis.” ECS Transactions 41 (10):15-22.

Ayers, K. 2015. Single Step Manufacturing of Low Catalyst Loading Electrolyzer MEAs. Advanced Manufacturing Office Annual Merit Review. Washington, D.C. May 28-29, 2015. https://www.energy.gov/sites/prod/files/2015/06/f23/P7-

AMO \%20Merit\%20Review\%202015\%20-\%20Proton\%20Final.pdf

BEA (U.S. Bureau of Economic Analysis). n.d. "Table C. BEA Rates of Depreciation, Service Lives, Declining-Balance Rates, and Hulten-Wykoff Categories.”

Bertuccioli, L., Chan, A., Hart, D., Lehner, F. Madden, B. Standen, E. 2014. Development of Water Electrolysis in the European Union. Fuel Cells and Hydrogen Joint Undertaking, February 2014.

Carmo, M., Fritz, D., Maier, W., Stolten, D. 2015. Alkaline Water Electrolysis vs. PEM Water Electrolysis - Exploring their Full Performance. 227th ECS Meeting. Chicago, 2015.

CBRE. n.d. Fit-Out Cost Guide: Occupier Project Management, EMEA, 2014 Edition.

Colella, W.G., James, B.D., Moton, J.M., Saur, G., Ramsden, T. 2014. Techno-economic Analysis of PEM Electrolysis for Hydrogen Production. Strategic Analysis Inc. Electrolytic Hydrogen Production Workshop. NREL, Golden, Colorado. February 2014. 
Contini, V., Eubanks, F., Heinrichs, M., Valluri, M., Jansen, M., George, P., Mansouri, M. 2016. Manufacturing Cost Analyses of Fuel Cell Systems for Primary Power and Combined Heat and Power Applications. Battelle 3/31/2017.

https://www.energy.gov/sites/prod/files/2017/05/f34/fcto_bop_workshop_contini.pdf

Haberl, J.S. (1993). Economic Calculations for the ASHRAE Handbook. Energy Systems Laboratory (http://esl.tamu.edu), Texas A\&M University; Department of Mechanical Engineering, Texas A\&M University.

Hamdan, M. 2011. Synergy of Giner, Inc./GES Technologies.

https://www.energy.gov/sites/prod/files/2014/03/f12/webinarslides052311_pemelectrolysis_ham dan.pdf

Hamdan, M. 2013. PEM Electrolyzer Incorporating an Advanced Low-Cost

Membrane. Washington, D.C.: U.S. Department of Energy. DOE/GO/18065-22.

https://www.osti.gov/servlets/purl/1091385.

Hansen, M.K. Aili, D., Christensen, E., Pan, C., Eriksen, S., Jensen, J.O., Barner, J.H., Li, Q., Bjerrum, N.J. 2012. PEM steam electrolysis at $130{ }^{\circ} \mathrm{C}$ using a phosphoric acid doped short side chain PFSA membrane. International Journal of Hydrogen Energy 37, 10992-11000

Howe-Baker International. 2017. Recovery and purification of Hydrogen using PSA technology. https://howe-baker.com/recovery-and-purification-of-hydrogen-using-psa-technology/

James, B., Colella, W., Moton, J., Saur, G., Ramsden, T. 2013. PEM Electrolysis H2A Production Case Study Documentation.

https://www.hydrogen.energy.gov/pdfs/h2a_pem_electrolysis_case_study_documentation.pdf

James, B.D., D.A. DeSantis. 2015. Manufacturing Cost and Installed Price Analysis of Stationary Fuel Cell Systems. Revision 3, 30 September 2015.

https://www.sainc.com/assets/site 18/files/publications/sa\%202015\%20manufacturing\%20cost $\% 20$ and $\% 20$ installed $\% 20$ price $\% 20$ of $\% 20$ stationary $\% 20$ fuel $\% 20$ cell $\% 20$ systems rev3.pdf

Kumar, A., Ricketts, M., Hirano, S. Ex situ evaluation of nanometer range gold coating on stainless steel substrate for automotive polymer electrolyte membrane fuel cell bipolar plate. Journal of Power Sources 195 (2010) 1401-1407

Lettenmeier, P., Kolb, S., Sata, N., Fallisch, A. Zielke, CL. Thiele, S., Gago A.S., Friedrich, K.A. 2017. Comprehensive investigation of novel pore-graded gas diffusion layers for highperformance and cost-effective proton exchange membrane electrolyzers. Energy Environ. Sci., $10,2521-2533$.

Liebreich, M. 2015. Bloomberg New Energy Finance Summit 2015. New York, April 2015. https://data.bloomberglp.com/bnef/sites/4/2015/04/BNEF 2014-04-08-ML-Summit-

Keynote_Final.pdf

Mayyas, A. Mann, M. Emerging Manufacturing Technologies for Fuel Cells and Electrolyzers. Accepted for publication in the Procedia Manufacturing/Elsevier, 2018. 
Pomerleau, Kyle. 2014. Corporate Income Tax Rates around the World, 2014. Washington, D.C.: Tax Foundation. No. 436. https://files.taxfoundation.org/legacy/docs/FF436 0.pdf.

Saggiorato, N., Wei, M., Lipman, T., Mayyas, A., Chan, S.H., Breunig, H., McKone, T., et al. 2017. A Total Cost of Ownership Model for Low Temperature PEM Fuel Cells in Combined Heat and Power and Backup Power Applications. Berkeley, CA: Lawrence Berkeley National Laboratory. https:/www.energy.gov/sites/prod/files/2017/02/f34/fcto 2016 tco model low temp pem fc.pdf.

Schmidt, O., Gambhir, Staffell, A. I., Hawkes, Nelson, A. J. Few, S. Future cost and performance of water electrolysis: An expert elicitation study. International journal of hydrogen energy 42 (2017) 30470-30492

Schmidt, O., Hawkes, A. I., Gambhir, A., Staffell, I. 2017. The future cost of electrical energy storage based on experience rates. Nature Energy 2, 17110.

THOMAS, D. 2018. Cost reduction potential for electrolyser technology. European Power-to-Gas. 18 June 2018, Berlin. http://europeanpowertogas.com/wpcontent/uploads/2018/06/20180619_Hydrogenics_EU-P2G-Platform_for-distribution.pdf

Turner \& Townsend. n.d. A Brighter Outlook: International Construction Cost Survey 2013. http://www.turnerandtownsend.com/media/1459/1349-1-icc-survey-brochureflipbook-final.pdf.

Wei, M., Lipman, T., Mayyas, A., et al. 2014. A Total Cost of Ownership Model for Low Temperature PEM Fuel Cells in Combined Heat and Power and Backup Power Applications. Environmental Energy Technologies Division. October 2014. https://www.energy.gov/sites/prod/files/2016/12/f34/fcto_tco_model_low temp_pem_fc.pdf PDR 3 (Hilton Chicago)

$\mathrm{Xu}, \mathrm{H}$. High-Performance, Long-Lifetime Catalysts for Proton Exchange Membrane Electrolysis. Hydrogen and Fuel Cell Technologies office Annual Merit Review. Washington, D.C. June 8, 2016. https://www.hydrogen.energy.gov/pdfs/review16/pd103 xu_2016_o.pdf

Yoon, W., Huang, X., Fazzino, P., Reifsnider, K.L. Akkaoui, M.A. 2008. Evaluation of coated metallic bipolar plates for polymer electrolyte membrane fuel cells. Journal of Power Sources $179,265-273$.

Yu, H., Danilovic, N., Zhao, S., Wang, Y., Capuano, C., Mustain, W.E., Ayers, K E. Maric, R. 2015. Manufacturing of Low Catalyst Loading PEM Electrolyzer Meas Using Reactive Spray Deposition Technology. 227th ECS Meeting. May 24-28, 2015, Chicago, IL. https://ecs.confex.com/ecs/227/webprogram/Paper48975.html 


\section{Appendix A. Functional Specification}

Functional specifications were estimated based on the average values for commercial PEM electrolyzers with similar size in $\mathrm{kW}$. Some examples of these commercial systems and their specifications are summarized in Table A1.

Functional cell dimensions were estimated based on typical cell size in some commercial PEM electrolyzers. Schematic of the cell dimensions including plate area, CCM coated area and cell active area, are shown in Figure A1 below. These areas were used in the bottom-up manufacturing cost analysis to determine the required material per system. Bipolar plate area was assumed to be $957 \mathrm{~cm}^{2}$, while cell total coated area $=748 \mathrm{~cm}^{2}$ with cell active area $=680 \mathrm{~cm}^{2}$, assuming $9 \%$ of the CCM coated area will be lost in bonding CCM to the seal/frame. Total frame width is $2.445 \mathrm{~cm}$ which includes $0.625 \mathrm{~cm}$ of each side that overlaps with the MEA and another $1.82 \mathrm{~cm}$ of each side that extend outside the MEA area. These estimates are based on suggested values by some of our industry advisors.

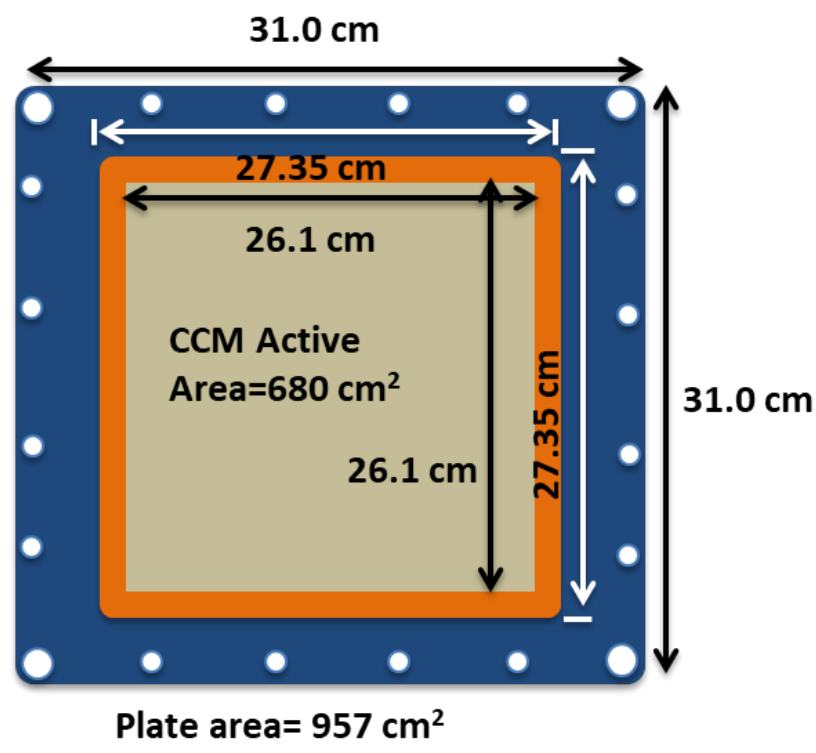

Figure A1. Functional cell dimensions

Loadings in $\left(\mathrm{g} / \mathrm{m}^{2}\right)$ of the platinum group metal (PGM) on anode and cathode side of the membrane were estimated based on discussions with industry advisors who suggested loadings of $7 \mathrm{~g} / \mathrm{m}^{2}$ of platinum on the anode side and $4 \mathrm{~g} / \mathrm{m}^{2}$ of platinum-iridium on the cathode side.

Current density and reference voltage at the cell level are two important parameters that play role in determining the cell efficiency and energy consumption per $\mathrm{kg}-\mathrm{H}_{2}$. We used average values from several polarization curves to estimate cell current density and voltage. Some examples of the polarization curves used in this analysis are shown in Figure A2. Power density was then used to calculate number of cells per stack to match it with the system size in $\mathrm{kW}$. 


\section{Technology Progression}

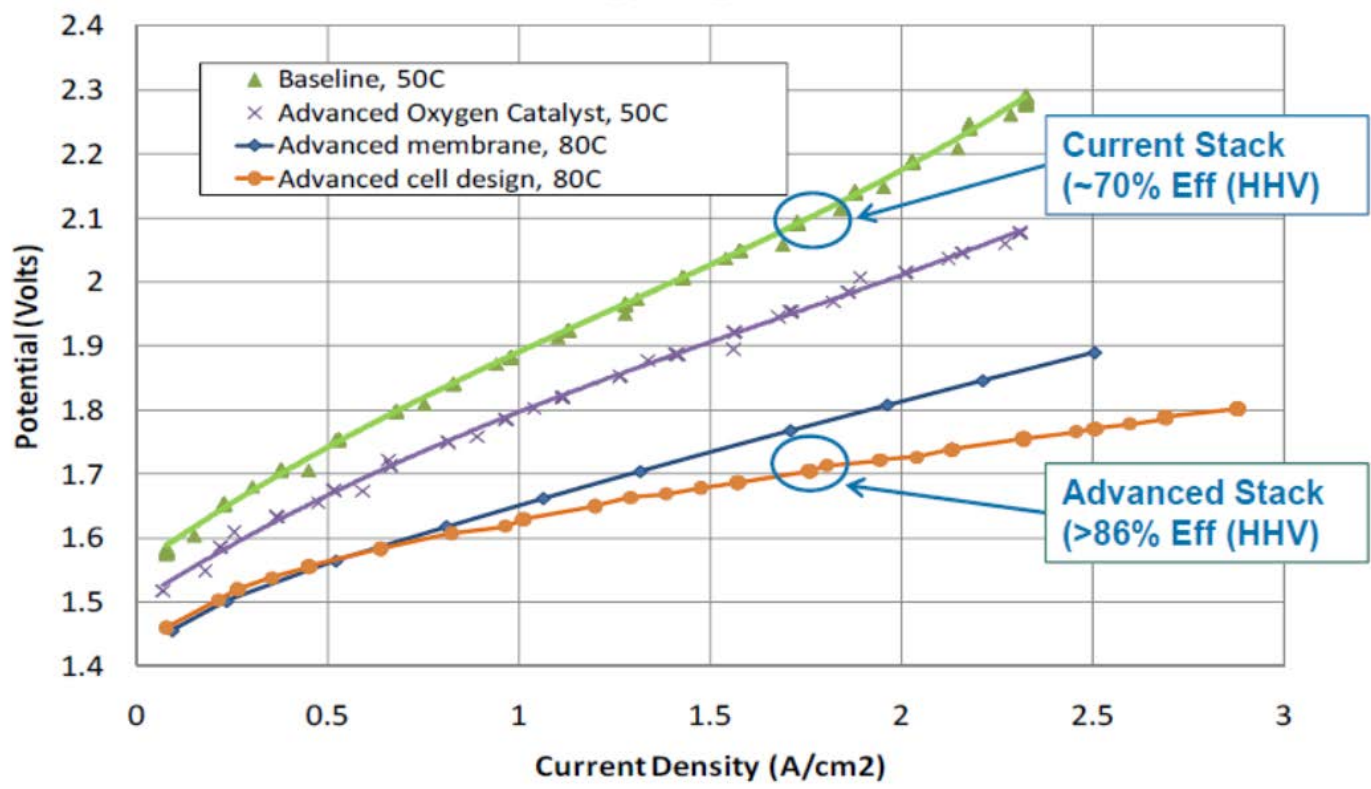

(a)

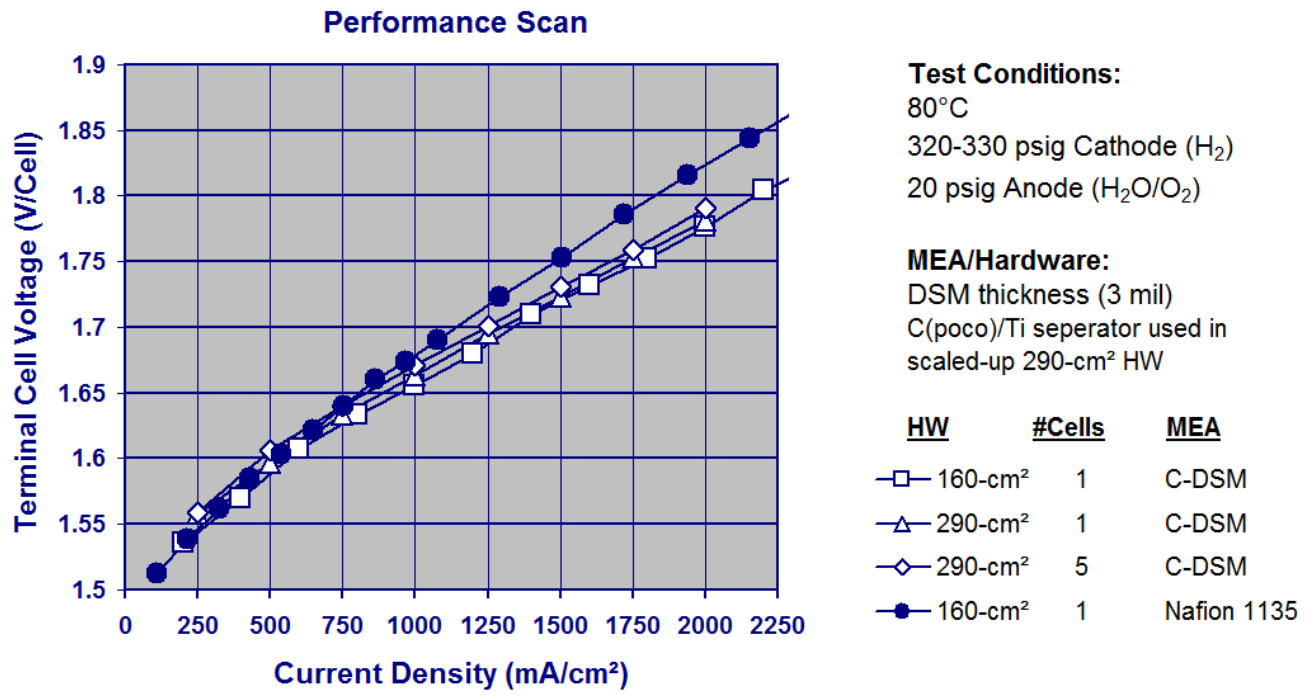

(b)

Figure A2. Example of the polarization curves for PEM electrolyzer cells Source of Images: Proton Onsite (Anderson et al. 2013) and Giner (Hamdan 2011) 
Table A1. Examples of commercial PEM electrolyzer and their specifications

\begin{tabular}{|c|c|c|c|c|c|c|c|c|c|}
\hline $\begin{array}{l}\text { Specificati } \\
\text { ons }\end{array}$ & $\begin{array}{l}\text { Hydroge } \\
\text { nics }^{\dagger}\end{array}$ & $\begin{array}{l}\text { Hydroge } \\
\text { nics }^{\dagger}\end{array}$ & $\begin{array}{l}\text { Proton } \\
\text { OnSite }^{\dagger} \\
+\end{array}$ & $\begin{array}{l}\text { Proton } \\
\text { OnSite }^{\dagger} \\
+\end{array}$ & $\begin{array}{l}\text { Proton } \\
\text { OnSite }^{\dagger} \\
+\end{array}$ & $\begin{array}{l}\text { Proton } \\
\text { OnSitett+ }\end{array}$ & Giner $\ddagger$ & Siemens & Units \\
\hline $\begin{array}{l}\text { Model } \\
\text { Number }\end{array}$ & $\begin{array}{l}\text { HyLYZE } \\
\mathrm{R}^{\mathrm{TM}}-1\end{array}$ & $\begin{array}{l}\text { HyLYZE } \\
R^{\mathrm{TM}}-2\end{array}$ & $\mathrm{H} 2$ & $\mathrm{H} 2$ & $\mathrm{H} 6$ & $\begin{array}{l}\text { FuelGen1 } \\
2 \text {, Series } \\
2\end{array}$ & $\begin{array}{l}\text { Merrim } \\
\text { ack }\end{array}$ & $\begin{array}{l}\text { SILYZER } \\
200 \text { basic }\end{array}$ & \\
\hline $\begin{array}{l}\text { Rated } \\
\text { stack } \\
\text { Consumpti } \\
\text { on } \\
\end{array}$ & 7.20 & 14.40 & 14.00 & 28.00 & 40.00 & 45.00 & 160.00 & 1250.00 & $\mathrm{~kW}$ \\
\hline $\begin{array}{l}\text { Startup } \\
\text { time: }\end{array}$ & & & & & & & $\begin{array}{l}\text { millise } \\
\text { cond } \\
\text { scale }\end{array}$ & $<10 \mathrm{sec}$ & $\mathrm{Sec}$ \\
\hline $\begin{array}{l}\text { Hydrogen } \\
\text { purity } \\
\text { (dep. on } \\
\text { operating } \\
\text { point): }\end{array}$ & & & $\begin{array}{c}99.999 \\
5 \% \\
\end{array}$ & $\begin{array}{c}99.999 \\
5 \% \\
\end{array}$ & $\begin{array}{c}99.999 \\
5 \% \\
\end{array}$ & $99.9995 \%$ & & $\begin{array}{c}99.5 \%- \\
99.9 \% \\
\end{array}$ & \\
\hline $\begin{array}{l}\text { Specific } \\
\text { Energy } \\
\text { Consumpti } \\
\text { on } \\
\end{array}$ & 6.70 & 6.70 & 7.30 & 7.00 & 6.80 & 7.50 & & 5.56 & $\begin{array}{l}\mathrm{kWh} / \mathrm{N} \\
\mathrm{m}^{3}\end{array}$ \\
\hline $\begin{array}{l}\text { Net } \\
\text { Production } \\
\text { Rate }\end{array}$ & 1 & 2 & 2 & 4 & 6 & 6 & 30.59 & 225 & $\mathrm{Nm}^{3} / \mathrm{h}$ \\
\hline $\begin{array}{l}\text { Net } \\
\text { Production } \\
\text { Rate (scfh) }\end{array}$ & 38 & 76 & 76 & 152 & 228 & 228 & 1162 & 8,550 & scfh \\
\hline $\begin{array}{l}\text { Net } \\
\text { Production } \\
\text { Rate } \\
\text { (kg/day) }\end{array}$ & 2.16 & 4.32 & 4.31 & 8.63 & 12.94 & 12.95 & 66.00 & 485.46 & $\mathrm{~kg} /$ day \\
\hline $\begin{array}{l}\text { Turndown } \\
\text { Ratio }\end{array}$ & $\begin{array}{c}0 \text { to } \\
100 \%\end{array}$ & & $\begin{array}{c}0 \text { to } \\
100 \% \\
\text { net } \\
\text { product } \\
\text { delivery } \\
\text { (Autom } \\
\text { atic) }\end{array}$ & $\begin{array}{l}0 \text { to } \\
100 \% \\
\text { net } \\
\text { product } \\
\text { delivery } \\
\text { (Autom } \\
\text { atic) } \\
\end{array}$ & $\begin{array}{l}0 \text { to } \\
100 \% \\
\text { net } \\
\text { product } \\
\text { delivery } \\
\text { (Autom } \\
\text { atic) }\end{array}$ & & $10: 1$ & & $\%$ \\
\hline $\begin{array}{l}\text { Output } \\
\text { pressure }\end{array}$ & Up to 7.9 & Up to 7.9 & & & & 15 & $\begin{array}{l}0-40 \\
\text { bar }\end{array}$ & Up to 35 & bar \\
\hline $\begin{array}{l}\text { Feed } \\
\text { Water }\end{array}$ & & & & & & $\begin{array}{l}\text { Potable } \\
\text { main } \\
\text { water } \\
\text { supply } \\
\end{array}$ & & & \\
\hline $\begin{array}{l}\text { Fresh } \\
\text { water } \\
\text { demand: }\end{array}$ & 1 & 1 & 1.83 & 3.66 & 5.5 & 54 & & 1.5 & $\begin{array}{l}\text { Itr / } \\
\mathrm{Nm}^{3} \mathrm{H} 2\end{array}$ \\
\hline $\begin{array}{l}\text { Inlet water } \\
\text { pressure }\end{array}$ & $0.7-6.9$ & $0.7-6.9$ & 1.5 to 4 & 1.5 to 4 & 1.5 to 4 & 1 to 10 & & & barg \\
\hline $\begin{array}{l}\text { Relative } \\
\text { Humidity }\end{array}$ & 0 to $90 \%$ & & $\begin{array}{l}0 \text { to } \\
90 \%\end{array}$ & $\begin{array}{l}0 \text { to } \\
90 \%\end{array}$ & $\begin{array}{l}0 \text { to } \\
90 \%\end{array}$ & & & & $\%$ \\
\hline $\begin{array}{l}\text { Power } \\
\text { Supply }\end{array}$ & $\begin{array}{r}208 / 120, \\
\text { wire+gnc } \\
200-260, \\
\text { wire+gnd } \\
\text { Direct col } \\
\text { DC poss } \\
\text { req }\end{array}$ & $\begin{array}{l}3 \text { phase }, 4 \\
, 50 / 60 \mathrm{~Hz} \\
1 \mathrm{phase}, 2 \\
50 / 60 \mathrm{~Hz} \\
\text { nection to } \\
\text { ible upon } \\
\text { lest. }\end{array}$ & $\begin{array}{c}380 \text { to } \\
480 \\
\text { VAC, } 3 \\
\text { phase, } \\
50 \text { or } \\
60 \mathrm{~Hz}\end{array}$ & $\begin{array}{l}380 \text { to } \\
480 \\
\text { VAC, } 3 \\
\text { phase, } \\
50 \text { or } \\
60 \mathrm{~Hz}\end{array}$ & $\begin{array}{c}380 \text { to } \\
480 \\
\text { VAC, } 3 \\
\text { phase, } \\
50 \text { or } \\
60 \mathrm{~Hz} \\
\end{array}$ & $\begin{array}{c}420-480 \\
\text { VAC, } 3 \\
\text { phase, } 60 \\
\text { Hz, } 112 \\
\text { FLA }\end{array}$ & & & \\
\hline
\end{tabular}




\begin{tabular}{|c|c|c|c|c|c|c|c|c|}
\hline $\begin{array}{l}\text { Cooling } \\
\text { strategy }\end{array}$ & $\begin{array}{c}\text { Air } \\
\text { Cooled }\end{array}$ & $\begin{array}{c}\text { Air } \\
\text { Cooled }\end{array}$ & $\begin{array}{l}\text { Liquid } \\
\text { cooled } \\
8.1 \mathrm{~kW}\end{array}$ & $\begin{array}{c}\text { Liquid } \\
\text { cooled } \\
16.1 \\
\mathrm{~kW}\end{array}$ & $\begin{array}{c}\text { Liquid } \\
\text { cooled } \\
23.7 \\
\text { kW }\end{array}$ & & Air Cooled & \\
\hline $\begin{array}{l}\text { Operating } \\
\text { Temperatu } \\
\text { re }\end{array}$ & 5 to 40 & 5 to 40 & 5 to 60 & 5 to 60 & 5 to 60 & -23 to 46 & & ${ }^{\circ} \mathrm{C}$ \\
\hline $\begin{array}{l}\text { Dimension } \\
\mathrm{s}\end{array}$ & $\begin{array}{c}0.75 X \\
0.66 X \\
1.17 \\
\end{array}$ & $\begin{array}{c}1.30 \mathrm{X} \\
1.00 \mathrm{X} \\
1.25 \\
\end{array}$ & $\begin{array}{c}180 \mathrm{~cm} \\
\times 81 \\
\mathrm{~cm} \mathrm{x} \\
191 \mathrm{~cm}\end{array}$ & $\begin{array}{c}180 \mathrm{~cm} \\
\times 81 \\
\mathrm{~cm} \mathrm{x} \\
191 \mathrm{~cm}\end{array}$ & $\begin{array}{c}180 \mathrm{~cm} \\
\times 81 \\
\mathrm{~cm} \mathrm{x} \\
191 \mathrm{~cm}\end{array}$ & $\begin{array}{c}2.18 \\
\times 0.84 \\
\times 1.91 \\
\end{array}$ & $\begin{array}{c}6.3 \times 3.10 \\
\times 3.00 \\
\end{array}$ & $\begin{array}{l}m X m X \\
m\end{array}$ \\
\hline Weight & 250 & 275 & 682 & 858 & 908 & 900 & 17000 & $\mathrm{~kg}$ \\
\hline
\end{tabular}

${ }^{\dagger}$ http://www.hydrogenics.com/wp-content/uploads/2-1-1-1-hylyzer-1-223F620871645.pdf

${ }^{\dagger+}$ https://www.protononsite.com/sites/default/files/2019-02/H\%20Series.pdf

${ }^{\mathrm{ttt}}$ http://proton.artbizcreative.com/backend/arc contenido/archivo21.pdf

${ }^{\ddagger}$ https://h2agentur.de/en/pem-electrolysis-stacks/\#merrimack

\# https://www.siemens.com/content/dam/webassetpool/mam/tag-siemens-com/smdb/corporatecore/sustainable energy/hydrogensolutions/brosch\%C3\%BCren/silyzer200-broschure-en.pdf 


\section{Appendix B. Bottom-Up Costing Analysis}

In this appendix, we discuss the economic analysis used in developing the direct manufacturing cost analysis. The model was adopted from the ASHRAE handbook; see Haberl (1993) and Wei et al. (2014) for details about the model. Below are definitions of terms used in developing economic equations:

$a_{b r}$ is the building area $\left(\mathrm{m}^{2}\right)$

$\mathrm{C}_{\mathrm{e}}$ is the energy cost for one accounting period (i.e., one year) (\$).

Cf is the factory floor space cost $\left(\$ / \mathrm{m}^{2}\right)$.

Clabor is the labor rate per hour $(\$ / \mathrm{hr})$.

Cs,assess is the initial assessed system value (\$).

$\mathrm{C}_{\text {s,salvage }}$ is the system salvage value at the end of its useful life in constant dollars.

$\mathrm{C}_{\text {s init }}$ is the initial system cost $(\$)$.

$\mathrm{C}_{\mathrm{y}}$ is the annualized system cost in constant dollars $(\$ / \mathrm{yr})$.

$\mathrm{D}_{\mathbf{k}, \mathbf{s l}}$ or $\mathrm{D}_{\mathbf{k}, \mathbf{S D}}$ is the amount of depreciation at the end of period $k$ depending on the type of depreciation schedule used, where $D_{\mathbf{k s}}$ is the straight-line depreciation method and $\mathrm{D}_{\mathrm{kSD}}$ represents the sum-of-digits depreciation method in constant dollars.

$\mathrm{F}$ is the future value $(\$)$.

$\mathrm{i}_{\mathbf{m}} \mathrm{P}_{\mathbf{k}}$ is the interest charged at the end of period $k(\$)$.

$\left.i^{\prime}=\left(i_{d}-j\right) / 1+j\right)$ is the effective discount rate adjusted for energy inflation, sometimes called the real discount rate.

$\left.\mathrm{i}^{\prime \prime}=\left(\mathbf{i}_{\mathbf{d}}-\mathbf{j}_{\mathbf{e}}\right) / 1+\mathrm{j}_{\mathbf{e}}\right)$ is the effective discount rate adjusted for energy inflation $\mathrm{j}_{\mathbf{e}}$.

$\mathrm{i}$ is the annual insurance costs.

ITC is the investment tax credit for energy efficiency improvements, if applicable. 
$\mathrm{j}$ is the general inflation rate per period.

$\mathrm{j}_{\mathrm{d}}$ is the discount rate.

$\mathrm{jbr}$ is the building depreciation rate.

$\mathrm{j}_{\mathrm{e}}$ is the general energy inflation rate per period.

$\mathrm{j}_{\mathrm{m}}$ is the average mortgage rate (real rate + general inflation rate).

$\mathrm{k}$ is the end if the period(s) in which replacement(s), repair(s), depreciation, or interest is calculated.

$\mathrm{M}$ is the periodic maintenance cost $(\$)$.

$\mathrm{n}$ is the number of period(s) under consideration (years).

$\mathrm{P}$ is the sum of money at the present time (i.e., its present value) (\$).

$\mathrm{P}_{\mathrm{k}}$ is the outstanding principle of the loan for $\mathrm{C}$-s, init at the end of period $\mathrm{k}$ in current dollars.

$\mathrm{R}_{\mathrm{k}}$ is the net replacement(s), repair cost(s), or disposals at the end of period $k$ in constant dollars.

$\mathrm{T}_{\text {inc }}$ is the (state tax rate + federal tax rate) - (state tax rate $\mathrm{X}$ federal tax rate) where tax rates are based on the last dollar earned (i.e., the marginal rates).

$\mathrm{T}_{\text {prop }}$ is the property tax rate.

$\mathrm{T}_{\mathrm{br}}$ is the salvage value of the building (\$).

For any proposed capital investment, the capital and interest costs, salvage costs, replacement costs, energy costs, taxes, maintenance costs, insurance costs, interest deductions, depreciation allowances, and other factors have to be weighed against the value of the services provided by the system (Haberl 1993).

\section{B.1 Single Payment}

The present value or present worth factor (PWF) is a common method for analyzing the impact of a future payment on the value of money at the present time. The primary underlying principle is that all present and future payments (in and out) can be evaluated according to their present purchasing power using a discounted cash flow method. The relationship between the present value $p$ and the future value $F$ with compound interest rate $i$ and accounting periods $n$ can be calculated as follows:

$$
F=p(1+i)^{n}
$$


The relationship between the present value $P$ or present worth factor $P W F$ and the future sum of money $F$ is given by:

$$
P=F /(1+i)^{n}=F \times P W F(i, n)
$$

where PWF(i,n) the present worth factor and can be calculated using the following equation:

$$
P W F(i, n)=1 /(1+i)^{n}
$$

\section{B.2 Accounting for Varying Inflation Rates}

Inflation is another important economic parameter that needs to be considered when converting future values to present values or vice versa. Inflation rate accounts for the rise in costs of goods and services over time. Inflation has an adverse effect on the economy, so governmentsthrough their central banks - try to limit it and avoid deflation in order to keep the economy running smoothly. One way to account for inflation in economic calculations is to use interest rates that account effectively for varying rates of inflation. Haberl (1993) suggested the following effective interest rate $i^{\prime}$, sometimes called the real rate, which considers the effects of general inflation $j$ and the discount rate $i_{d}$. Effective interest rate can be expressed as follows:

$$
i^{\prime}=\frac{1+i_{d}}{1+j}-1=\frac{i_{d}-j}{1+j}
$$

However, this expression can also be used to account for energy inflation by considering the general discount rate $i_{d}$ and the energy inflation rate $j e$, thus:

$$
i^{\prime \prime}=\frac{1+i_{d}}{1+j_{e}}-1=\frac{i_{d}-j_{e}}{1+j_{e}}
$$

Based on these equations, we can revise the equation of the future value $F$, using constant currency of an invested sum $P$ with a discount rate $i_{d}$ under inflation $i$ during $n$ periods:

$$
F=P\left[\frac{1+i_{d}}{1+j}\right]^{n}=P\left(1+i^{\prime}\right)^{n}
$$

The present worth $P$, in constant dollars, of a future sum of money $F$ with discount rate $j_{d}$ under inflation rate $j$ during $n$ periods is:

$$
P=F /\left[\frac{1+j_{d}}{1+j}\right]^{n}
$$

In constant currency, the present worth $P$ of a sum of money $F$ can be expressed using the effective interest rate $i^{\prime}$, which is adjusted for inflation by:

$$
P=F /\left(1+i^{\prime}\right)^{n}=F \times P W F\left(i^{\prime}, n\right)
$$

Similarly, the effective present worth factor PWF can be calculated using the following equation: 


$$
P W F\left(i^{\prime}, n\right)=1 /\left(1+i^{\prime}\right)^{n}
$$

\section{B.3 Recovering Capital as a Series of Payments}

Another important economic concept is the recovery of capital as a series of uniform payments or what is called the capital recovery factor. It is commonly used to describe periodic uniform mortgage or loan payments. $S$ is the ratio of the periodic payment to the total sum being repaid. The discounted sum $S$ of such an annual series of payments $A$ invested over $n$ periods with interest rate $i$ is given by:

$$
\begin{gathered}
S=A\left[1 \pm(1+i)^{-n} / i\right. \\
A=(S \times i) /\left[1+(1+i)^{-n} / i\right. \\
C R F(i, n)=\frac{i}{\left[1-(1+i)^{-n}\right]}=\frac{i(1+i)^{n}}{(1+i)^{n}-1}
\end{gathered}
$$

Table B-1 summarizes some of the mathematical formulas used in calculating these cost components.

Table B.1. Cost Components and Their Mathematical Formulas [from Haberl (1993)]

\begin{tabular}{lc}
\hline Cost Component & Formula \\
\hline Building cost & $\mathrm{C}_{\mathrm{br}}=C R F_{m} \times c_{f s} \times a_{b r}$ \\
\hline Capital and Interest & $\left(C R F_{i, i n i t}-I T C\right) C R F\left(i^{\prime}, n\right)$ \\
\hline Depreciation & $T_{\text {inc }} \sum_{k=1}^{n}\left[D_{k} P W F\left(i_{d}, k\right)\right] C R F\left(i^{\prime}, n\right)$ \\
\hline Insurance & $I\left(1-T_{i n c}\right)$ \\
\hline Interest tax deduction & $T_{i n c}^{n}\left[j_{m} P_{k-1} P W F\left(i_{d}, k\right)\right] C R F\left(i^{\prime}, n\right)$ \\
\hline Maintenance & $M\left(1-T_{i n c}\right)$ \\
\hline Operating energy & $C_{e}\left[\frac{C R F\left(i^{\prime}, n\right)}{C R F\left(i^{\prime \prime}, n\right)}\right]\left(1-T_{i n c}\right)$ \\
\hline $\begin{array}{l}\text { Principle } P_{k} \text { during year } K \\
\text { at market mortgage rate } i_{m}\end{array}$ & $P_{k}=\left(C_{i, i n i t}-I T C\right)\left[\left(1+j_{m}\right)^{k-1}\right.$ \\
$\left.+\frac{\left(1+j_{m}\right)^{k-1}-1}{\left(1+j_{m}\right)^{-n}-1}\right]$ \\
\hline
\end{tabular}




\begin{tabular}{lc}
\hline Cost Component & Formula \\
\hline Property tax & $C_{s, \text { assess }} T_{\text {prop }}\left(1-T_{\text {inc }}\right)$ \\
\hline Replacement or disposal & $\sum_{k=1}^{n}\left[R_{k} P W F\left(i^{\prime}, k\right)\right] C R F\left(i^{\prime}, n\right)(1$ \\
& $\left.-T_{\text {inc }}\right)$ \\
\hline Salvage value & $\left(C_{s, s l v} P W F\left(i^{\prime}, n\right) C R F\left(i^{\prime}, n\right)(1\right.$ \\
& $\left.-T_{\text {salv }}\right)$ \\
\hline
\end{tabular}




\section{Appendix C. Assumptions Used in Developing the Direct Manufacturing Costs Analysis}

Following tables summarize some important manufacturing process parameters and some related part specifications used in developing the bottom-up manufacturing cost models.

Table C.1. Manufacturing parameter for spray coating process of the catalyst coated membrane

\begin{tabular}{|c|c|c|}
\hline Parameter & Value & Source/Notes \\
\hline Nafion membrane cost & $\begin{array}{l}\text { Variable (the lowest assumed } \\
\text { value }=\$ 500 / \mathrm{m}^{2} \text { ) }\end{array}$ & \\
\hline $\begin{array}{l}\text { Coating line cost } \\
\text { (Ultrasonic Spray Coating) }\end{array}$ & $\$ 1,000,000$ & $\begin{array}{l}\text { Based on similar spray coating } \\
\text { lines used in production of } \\
\text { photovoltaic, li-ion battery } \\
\text { electrodes, etc. }\end{array}$ \\
\hline Coating line footprint & $88.2 \mathrm{~m}^{2}$ & \\
\hline Spray coating process yield & $90 \%$ & \\
\hline Line speed & $50 \mathrm{~cm} / \mathrm{min}$ & $\begin{array}{l}\underline{\mathrm{http}: / / \text { www.sono- }} \\
\text { tek.com/flexicoat-oversize- } \\
\underline{\text { ultrasonic-coating-system/ }}\end{array}$ \\
\hline Web width & $109 \mathrm{~cm}$ & Width of 4 CCMs \\
\hline $\begin{array}{l}\text { Platinum group metal } \\
\text { loading }\end{array}$ & $\begin{array}{l}7 \mathrm{~g} / \mathrm{m}^{2} \text { (anode): Pt only } \\
4 \mathrm{~g} / \mathrm{m}^{2}: 1: 1 \mathrm{Pt}: \mathrm{Ir}\end{array}$ & $\begin{array}{l}\text { Using similar values for } \\
\text { commercial PEM systems }\end{array}$ \\
\hline Pt price & $\$ 1,500 /$ tr.oz & FCTO value for 2017 \\
\hline Ir price & $\$ 23.63 / \mathrm{g}$ & Average spot price for 2017 \\
\hline Nafion ionomer & $\$ 1.53 / \mathrm{g}$ & $\begin{array}{l}\text { D2020 Nafion Dispersion - } \\
\text { Alcohol based } 1000 \text { EW at } 20 \\
\text { wt } \%\end{array}$ \\
\hline Solvents & $\$ 10$ per gallon & Alcoholic solvent \\
\hline Workers/line & 2 workers & Hourly paid workers \\
\hline
\end{tabular}


Table C.2. Manufacturing parameter for Powder metallurgy of the Porous Transport Layer

\begin{tabular}{|c|c|c|}
\hline Parameter & Value & Source/Notes \\
\hline $\begin{array}{l}\text { Titanium powder } \\
\text { cost }\end{array}$ & $\$ 35 / \mathrm{kg}$ & Average price for high purity Titanium powder \\
\hline $\begin{array}{l}\text { Powder metallurgy } \\
\text { production line }\end{array}$ & $\$ 1,500,000$ & $\begin{array}{l}\text { Includes compacting press, sintering oven, powder } \\
\text { mixing system, powder pumping system and } \\
\text { quality control unit }\end{array}$ \\
\hline Gold coating layer & $\begin{array}{l}100 \mathrm{~nm} \\
\$ 41 \text { per gram }\end{array}$ & $\begin{array}{l}\text { Kumar at al., (2010); Yoon et al., (2008). Physical } \\
\text { vapor deposition (PVD) }\end{array}$ \\
\hline Carbon cloth cost & $\$ 200-500 / \mathrm{m}^{2}$ & $\begin{array}{l}\text { Carbon cloth: Toray Paper } 090 \text { - TGP-H-090 } \\
\text { (thickness }=280 \mu \mathrm{m})\end{array}$ \\
\hline $\begin{array}{l}\text { Physical Vapor } \\
\text { Deposition Machine }\end{array}$ & $\$ 400,000$ & \\
\hline $\begin{array}{l}\text { Production line } \\
\text { footprint }\end{array}$ & $150 \mathrm{~m}^{2}$ & \\
\hline $\begin{array}{l}\text { Powder metallurgy } \\
\text { process yield }\end{array}$ & $99 \%$ & \\
\hline $\begin{array}{l}\text { Coating process } \\
\text { yield }\end{array}$ & 99.9 & \\
\hline P/M Line throughput & 2 pieces/min & \\
\hline Workers/line & 4 workers & $\begin{array}{l}\text { Hourly paid workers } \\
\text { ( } 2 \text { workers for P/M line, and } 2 \text { workers for coating } \\
\text { production line) }\end{array}$ \\
\hline
\end{tabular}


Table C.3. Manufacturing parameter for injection molding of the Seal/Frame

\begin{tabular}{|c|c|c|}
\hline Parameter & Value & Source/Notes \\
\hline $\begin{array}{l}\text { Width of the } \\
\text { frame }\end{array}$ & $\begin{array}{l}0.625 \mathrm{~cm} \text { from all } \\
\text { edges of the MEA } \\
\text { Total frame width }= \\
2.445 \mathrm{~cm}\end{array}$ & 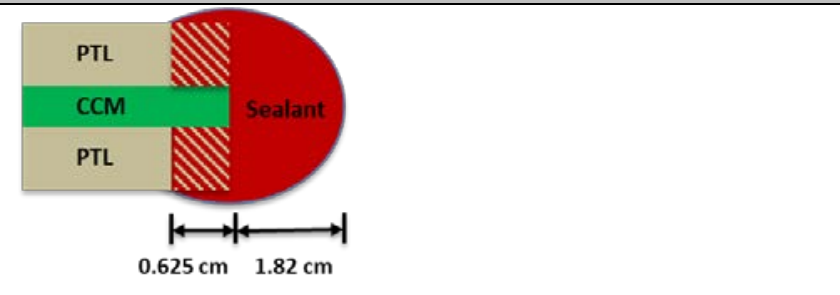 \\
\hline $\begin{array}{l}\text { PPS- } 40 \% \mathrm{GF} \\
\text { resin cost } \\
(\$ / \mathrm{kg})\end{array}$ & $\$ 15.40 / \mathrm{kg}$ & $\begin{array}{l}\text { http://www.plasticsnews.com/resin/high- } \\
\text { temperature-thermoplastics/current-pricing }\end{array}$ \\
\hline $\begin{array}{l}\text { Injection } \\
\text { molding } \\
\text { production line }\end{array}$ & $\$ 700,000$ & $\begin{array}{l}\text { Includes injection molding machine, curing } \\
\text { oven, and quality control unit }\end{array}$ \\
\hline $\begin{array}{l}\text { Production line } \\
\text { footprint }\end{array}$ & $100 \mathrm{~m}^{2}$ & \\
\hline Process yield & $99 \%$ & \\
\hline $\begin{array}{l}\text { Line } \\
\text { throughput }\end{array}$ & 2 pieces/min & $\begin{array}{l}\text { Including the time required for injection molding } \\
\text { and quality checking }\end{array}$ \\
\hline Workers/line & 2 workers & Hourly paid workers \\
\hline
\end{tabular}


Table C.4. Manufacturing parameter for stamped and coated bipolar plates

\begin{tabular}{|c|c|c|}
\hline Parameter & Value & Source/Notes \\
\hline $\begin{array}{l}\text { Stainless steel } \\
\text { 316L cost }\end{array}$ & $\$ 5 /$ piece & Plate area $957.44 \mathrm{~cm}^{2}$ \\
\hline $\begin{array}{l}\text { Gold coating } \\
\text { layer }\end{array}$ & $\begin{array}{l}100 \mathrm{~nm} \\
\$ 41 \text { per gram }\end{array}$ & $\begin{array}{l}\text { Kumar at al., (2010); Yoon et al., (2008). } \\
\text { Physical vapor deposition (PVD) }\end{array}$ \\
\hline $\begin{array}{l}\text { Consumables } \\
\text { cost }\end{array}$ & $\$ 0.60 /$ piece & Including alcohol for cleaning \\
\hline Production line & $\$ 1,500,000$ & $\begin{array}{l}\text { Includes stamping press, PVD machine, quality } \\
\text { control unit (scanning electron microscope and } \\
\text { material characterization) }\end{array}$ \\
\hline $\begin{array}{l}\text { Production line } \\
\text { footprint }\end{array}$ & $100 \mathrm{~m}^{2}$ & \\
\hline $\begin{array}{l}\text { Stamping } \\
\text { process yield }\end{array}$ & $95 \%$ & \\
\hline $\begin{array}{l}\text { PVD coating } \\
\text { process yield }\end{array}$ & $99.9 \%$ & \\
\hline $\begin{array}{l}\text { Stamping line } \\
\text { throughput }\end{array}$ & $11 \mathrm{pieces} / \mathrm{min}$ & Using precise stamping press \\
\hline Workers/line & 3 workers & Hourly paid workers \\
\hline
\end{tabular}


Table C.5. Manufacturing parameter for stack assembly process

\begin{tabular}{|l|l|l|}
\hline Parameter & Value & Source/Notes \\
\hline $\begin{array}{l}\text { Assembly line } \\
\text { type }\end{array}$ & Variable & $\begin{array}{l}\text { 3 assembly lines assumed in this study: manual (for } \\
\text { MEAs } \leq 100,000 / \text { yr; semi-automatic } \leq 700,000 \text {, and } \\
\text { fully automatic (MEAs } \geq 700,000)\end{array}$ \\
\hline Assembly line & $\begin{array}{l}\$ 0.5 \mathrm{M} \text { (manual) } \\
\$ 1 \mathrm{M} \text { (Semi- } \\
\text { automatic) } \\
\$ 2 \mathrm{M} \text { (Automatic) }\end{array}$ & $\begin{array}{l}\text { Includes robots, compacting press, stack } \\
\text { conditioning station, and quality testing station }\end{array}$ \\
\hline $\begin{array}{l}\text { Production line } \\
\text { footprint }\end{array}$ & $150 \mathrm{~m}^{2}$ & $\begin{array}{l}\text { For each assembly line. More than 1 assembly line } \\
\text { may be needed for larger annual production rates. }\end{array}$ \\
\hline $\begin{array}{l}\text { Assembly } \\
\text { yield }\end{array}$ & $99.5 \%$ & $\begin{array}{l}\text { Depending on the stack size in } \mathrm{kW} \text { (i.e., number of } \\
\text { assembled MEAs per stack) }\end{array}$ \\
\hline $\begin{array}{l}\text { Index time } \\
\text { assembly } \\
\text { time) }\end{array}$ & Variable & $\begin{array}{l}\text { Using precise stamping press } \\
\text { assembly, 3 workers/line for semi-automatic, and 2 } \\
\text { workers/line for fully automatic line }\end{array}$ \\
\hline $\begin{array}{l}\text { Line } \\
\text { throughput }\end{array}$ & 11 pieces/min &
\end{tabular}

